\title{
A RESPONSABILIDADE CIVIL DA PESSOA ADULTA INCAPAZ NÃO INCAPACITADA E A DE SEU GUARDIÃO DE FATO POR DANOS CAUSADOS A TERCEIROS
}

\author{
Civil liability of impaired, non-handicapped adults and of their de facto \\ guardians for damages caused to third parties
}

Nelson ROSENVALD ${ }^{1}$

\begin{abstract}
Resumo: Pode-se definir a guarda de fato como uma situação em que uma pessoa se encarrega do cuidado de outra, que necessita de proteção, sem intervenção administrativa ou judicial, e à margem da existência de um dever legal. As pessoas submetidas a guarda de fato costumam ser maiores em situações de dependência, que carecem de condições materiais e afetivas e que se integram em uma família sem que existam vínculos de parentesco, ou que por sua condição psíquica ou intelectual poderiam estar incapacitadas, mas não estão. Podemos dizer que existem três formas de proteção e promoção de direitos fundamentais da pessoa com deficiência mental ou psíquica: a) curatela; b) tomada de decisão apoiada; c) guarda de fato. Não obstante as duas primeiras sejam modelos jurídicos disciplinados na legislação civil brasileira, a guarda de fato surge como tertium genus, consistindo em uma atuação imediata sobre pessoas maiores cuja capacidade não tenha sido judicialmente modificada, mas em tese deveriam ter sido curateladas por se encontrarem em situação de ausência de autogoverno ou, necessitem de proteção por terem limitações em suas faculdades volitivas que as coloquem em situação de risco, sem que tenham sido submetidas a tomada de decisão apoiada. Há de se indagar se - em face do silêncio do Código Civil há a possibilidade de imputação pessoal de danos a uma pessoa maior incapaz (porém não incapacitada) por danos praticados contra terceiros e também da pessoa que exerça a guarda de fato sobre ela. A questão se torna mais aguda à medida que a demografia brasileira aponta para o envelhecimento da população e o consequente aumento de doenças crônicas degenerativas e incapacitantes.
\end{abstract}

Palavras-chave: Guarda de Fato. Pessoas com deficiência. Incapacidade. Curatela. Responsabilidade civil.

\footnotetext{
${ }^{1}$ Pós-Doutor em Direito Civil pela Universidade Roma Tre (IT). Pós-Doutor em Direito Societário pela Universidade de Coimbra. Doutor e Mestre em Direito Civil pela PUC-SP. Procurador de Justiça do Ministério Público de Minas Gerais. Professor de Direito Civil. ORCID: https://orcid.org/0000-00024123-0158
} 
Abstract: De facto guardianship can be defined as a situation in which one person takes it upon him or herself to care for another who needs protection, without administratively or legally intervening and at the borderline of the existence of a legal duty. Persons submitted to de facto guardianship many times are adults in dependency situations who lack material and emotional conditions and are family members without being relatives or who, due to their mental or intellectual condition, may be impaired, but in fact are not. We can say that there are three forms of protection and promotion of an impaired person's fundamental rights with a mental deficiency: a) curating; b) supported decision making; c) and de facto guardianship. In spite of the first two existing in legal models in Brazilian civil law, de facto guardianship has arisen as a tertium genus, consisting in immediate action over adult persons whose capacity has not been legally altered, rather, theoretically, should have been curated, as they are in a situation of the absence of self-governance or in need of protection due to limitations in their willful faculties, placing them in situations of risk and without having been submitted to the supported decision making process. Due to the lack of provision in the Civil Code, it is important to question the possibility of personal damage liability against an impaired (but not legally impeded) adult person being held responsible for damages against third parties, as well as against the person who exercises de facto guardianship over that person. The issue has become more critical with the aging population demographics in Brazil and consequent increase in chronic, degenerative and incapacitating illnesses.

Keywords: De facto guardianship, impaired persons; incapacity; curating; civil liability.

Sumário: Introdução; 1. A Responsabilidade Civil da Pessoa com Deficiência não Curatelada; 2. A Responsabilidade Civil pela guarda de fato de pessoas maiores com deficiência; 2.1. Compreendendo a guarda de fato; 2.2 Guarda de fato $\mathrm{e}$ responsabilidade civil; 2.3 Responsabilidade civil dos pais como guardiões de fato; 2.4 A Responsabilidade Civil do guardião de fato por danos causados por idosos 2.4.1 A Vulnerabilidade Potencializada do Idoso; 2.4.2 A Responsabilidade Indireta do Guardião; 2.5 A Responsabilidade Civil nas hipóteses de dissociação entre a titularidade e o exercício efetivo da guarda; Conclusão. Referências.

\section{Introdução}

A Responsabilidade é o reverso da liberdade. Na medida em que a Convenção Internacional das Pessoas com Deficiência (CDPD) reconhece que "as pessoas com deficiência gozam de capacidade legal em igualdade de condições com as demais pessoas em todos os aspectos da vida" (art. 12.2) ${ }^{2}$ e a Lei 13.146/2015 (EPD) estatui

\footnotetext{
${ }^{2}$ Estabelece a Carta de Direitos Fundamentais da União Europeia que: "Artigo $3^{\circ}$ Direito à integridade do ser humano 1. Todas as pessoas têm direito ao respeito pela sua integridade física e mental. 2. No domínio da medicina e da biologia, devem ser respeitados, designadamente: o consentimento livre e esclarecido da pessoa, nos termos da lei".
} 
que "a deficiência não afeta a plena capacidade civil da pessoa" (art. $6^{\circ}$ ), fíca evidenciada uma presunção de capacidade e garantia de autodeterminação a todas as pessoas com deficiência - incluindo-se aquelas com impedimentos mentais e intelectuais. A proteção de adultos vulneráveis é intimamente vinculada ao respeito por direitos humanos, pois toda pessoa que se encontre em tal situação será considerada titular de direitos e apta a tomar decisões livres e informadas nos limites de sua capacidade e não simplesmente ser um passivo destinatário de cuidado e atenção. Lado outro, essa liberdade pode ser objetada por expor muitas pessoas com desordens psicológicas ou deficiências a uma significativa autonegligência, exploração por outros e comportamentos de riscos que eventualmente derivarão em sua responsabilidade pessoal por danos causados contra terceiros, bem como a responsabilidade indireta daqueles que assumem a função de guardiões de fato da pessoa impossibilitada de proteção de seus interesses, apesar de não se encontrar formalmente incapacitada. ${ }^{3}$

\section{A responsabilidade civil da pessoa com deficiência não curatelada}

A participação e inclusão plena e efetiva de pessoas com deficiência nos campos civil, político, econômico, social e cultural significa que essas pessoas são potenciais produtores de riscos e danos, que serão por elas assumidos. Seria um equívoco crer que a pessoa com deficiência seria melhor protegida com a exoneração de responsabilidade por seus próprios atos. Esse paternalismo contribuiria para que aquelas pessoas continuassem a se sentir marginalizadas, somando-se ao fato de que a inclusão social não seria completa, na medida em que o resto dos cidadãos teria sérias reservas para se relacionar com pessoas a quem a lei imuniza de responsabilidade.

Em acréscimo, e, de forma pragmática, a responsabilização da pessoa com deficiência atende ao princípio da reparação integral, evitando que a vítima não seja

\footnotetext{
${ }^{3}$ O'Shea Tom: "Should the legal capacity to decide for oneself be dependent upon mental capacity? For example, ought it be legally permissible to make decisions for others if their own decision-making abilities seem to be curtailed by dementia or depression? Supporters claim this ensures respects for choices people are able to make competently, while protecting them when poor mental health or cognitive disability impairs their decision making, whereas opponents maintain that this would deprive people with mental disorders or cognitive disabilities of the same legal capacity enjoyed by others. This invites the objection that it would expose many people with psychological disorders or disabilities to significantly greater self-neglect, risk behavior and exploitation by others". In: A civic republican analysis of mental capacity law. In Legal studies - The society of legal scholars. Volume 38, n. 1: Cambridge Press, March 2018 , p. 147.
} 
ressarcida nas hipóteses em que os responsáveis de direito ou de fato sejam insolventes. Podemos ilustrar com um idoso titular de portentoso patrimônio, com uma doença crônica progressiva que mitiga o autogoverno, tendo um único filho a exercer a guarda de fato e somente titularizando o bem de família. Caso se excluísse a responsabilidade pelo simples fato do transtorno psíquico, a vítima se colocaria em situação de negação de acesso a dois patrimônios: um pela insuficiência e outro pela blindagem da condição humana da deficiência.

Vale dizer, no delicado concerto entre autonomia e controle, a balança pende inicialmente para a promoção da liberdade, sem qualquer contenção heterônoma na realização do modus vivendi. ${ }^{4}$ Todavia, na tênue linha entre a plena aceitação do estilo de vida de uma pessoa com deficiência psíquica ou o controle de atos e atividades por meio da curatela, o ordenamento jurídico tolerará excepcional restrição na esfera de autonomia quando, apesar de todas as tentativas de adaptação social às vicissitudes daquela pessoa, não é possível a ela se fazer compreender perante a família e a coletividade.

O fato é que a CDPD omite qualquer referência expressa às obrigações ou responsabilidades das pessoas com deficiência. Talvez, possamos inferi-las do art. 8., referentes ao compromisso dos Estados Partes, de adotar medidas imediatas, efetivas e pertinentes para "b) Combater estereótipos, preconceitos e práticas nocivas em relação a pessoas com deficiência". Isentar as pessoas com deficiência da responsabilidade civil correspondente por danos causados a terceiros constitui um estigma que deveria ser eliminado. Ou, de forma mais veemente e com base no art. 12.5 da convenção internacional, compreender que se "Os Estados Partes, sujeitos ao disposto neste Artigo, tomarão todas as medidas apropriadas e efetivas para assegurar às pessoas com deficiência o igual direito de possuir ou herdar bens, de controlar as próprias finanças e de ter igual acesso a empréstimos bancários, hipotecas e outras formas de crédito financeiro, e assegurarão que as pessoas com deficiência não sejam arbitrariamente destituídas de seus bens", inequivocamente, como detentores de direitos e obrigações,

\footnotetext{
4 Nesse sentido Maria Celina Bodin de Moraes anota que "O princípio da liberdade individual consubstancia-se, hoje, numa perspectiva de privacidade, intimidade e livre exercício da vida privada. Liberdade significa, cada vez mais, poder realizar, sem interferências de qualquer gênero, as próprias escolhas individuais -mais: o próprio projeto de vida, exercendo-o como melhor convier". In: Na medida da pessoa humana - Estudos de direito civil constitucional. Rio de Janeiro: Renovar, 2010, p. 108.
} 
também podem ser obrigados a pagar e compensar os danos causados a terceiros desde que, evidentemente, se manifestem os demais pressupostos da responsabilidade.

Em sentido contrário, poder-se-ia alegar que não obstante plenamente capaz, a pessoa com deficiência ainda poderia ser considerada inimputável, à medida que a presunção de imputabilidade cederia quando provado que, concretamente, careceria o agente de condições psíquicas de compreensão sobre o caráter reprovável de sua conduta. Todavia, se consideramos o conceito contemporâneo de "culpa" como uma aferição baseada em critérios abstratos de standards de condutas previamente reconhecidos - ao invés de uma investigação que desvele a psique do agente - o magistrado se eximirá da árdua tarefa de apontar a existência de uma inaptidão específica do autor do dano, a fím de desresponsabilizá-lo pelo ilícito. ${ }^{5}$

Nada obstante, mesmo quando a capacidade legal se afirma, o legislador não pode encobrir a vulnerabilidade ínsita a qualquer pessoa com deficiência. Um impedimento mental, intelectual, físico ou sensorial, ou seja, uma "diferença", fatalmente determina uma desigualdade de fato que demanda tratamento diferenciado por parte do ordenamento jurídico. Transpondo a sutileza da tensão entre o binômio capacidade/vulnerabilidade para o campo da responsabilidade civil, qual seria a melhor forma do direito obrigacional emprestar eficácia às consequências econômicas de um dano causado por uma pessoa plenamente capaz, porém dotada de uma peculiar condição orgânica?

Aplicar simplesmente o artigo 927 do Código Civil - "Aquele que, por ato ilícito (arts. 186 e 187), causar dano a outrem, fica obrigado a repará-lo" -, impondo à pessoa com deficiência um tratamento absolutamente paritário em termos compensatórios a qualquer outra pessoa que cause um dano injustificado por ato comissivo ou omissivo, seria uma completa recusa à proteção dessa categoria especial, frustrando o projeto de igualdade substancial acalentado pela legislação. Por outro lado, homenagear a pessoa vulnerável com a extensão a ela da responsabilidade subsidiária e mitigada do art. 928

\footnotetext{
${ }^{5}$ De acordo com Caitlin Mulholland, "Considerando essa renovada concepção de culpa, pode-se concluir que na investigação da conduta causadora do dano, realizada por pessoa com deficiência intelectual, há uma facilitação na identificação de culpa, na medida em que é levada em conta muito mais a contrariedade ao direito e a violação de standards abstratos de conduta, do que uma investigação psicológica da culpa, que leva necessariamente a avaliação da capacidade de reconhecimento da conduta culposa como potencial causadora do dano". In: A responsabilidade civil da pessoa com deficiência psíquica e/ou intelectual. In: MENEZES, Joyceane Bezerra (Org.). Direito das pessoas com deficiência psíquica ou intelectual nas relações privadas. Rio de Janeiro: Processo, 2016, p. 648.
} 
do Código Civil - tal e qual se defere à pessoa incapaz -, seria admitir que "a vulnerabilidade é o novo design da incapacidade", como mero jogo de palavras de um politicamente correto. Certamente essa não é a melhor hermenêutica, reservando-se a responsabilidade subsidiária apenas aos casos extremos de incapacidade relativa subsequente à curatela judicial.

Parece-nos que a melhor forma de arbitrar a vulnerabilidade existencial da pessoa com deficiência (que difere da vulnerabilidade patrimonial de um consumidor ou empregado) será a de inicialmente admitir a imputação pessoal e direta das consequências econômicas do mau uso da liberdade, pela via da trasladação dos danos ao autor do ilícito, na qualidade de pessoa plenamente capaz, tal como refere o citado art. 927 do Código Civil. Todavia, o handicap intelectual ou mental do demandado justifica alguma forma de atuação do princípio da equidade em termos de tutela diferenciada, não mais como próprio fundamento da responsabilidade (tal como se dá com o curatelado relativamente incapaz), porém, no âmbito exclusivo da mitigação do quantum reparatório, em mais uma exceção à regra da restitutio in integro do art. 944 do Código Civil.

Em outras palavras, defende-se uma casuística extensão do parágrafo único do art. 928 do Código Civil à pessoa com deficiência, como norma de abertura para um arbitramento equitativo de danos patrimoniais e morais, sempre que se desincumbam do ônus probatório de demonstrar que, apesar de não submetido à curatela, estava privado de integral consciência sobre as consequências danosas de seu comportamento antijurídico. Para além de uma vulnerabilidade "abstrata", cabe ao réu do processo indenizatório demonstrar pelas circunstâncias do fato, o seu desnível concreto em termos de compreensão do caráter da conduta danosa, o que servirá como guia para o magistrado proporcionalizar a condenação, preservando um acervo patrimonial que se funcionalize como mínimo existencial do autor do ilícito, instrumental para a sobrevivência digna de uma pessoa concretamente vulnerável.

Consequentemente, o padrão de conduta aplicável às pessoas com deficiência é susceptível de ser adaptado às características psíquicas do grupo de pessoas a quem o dano pertence, de acordo com certos parâmetros. A evolução experimentada nesta área é significativa: ao invés de exonerar essas pessoas da responsabilidade porque não podem se adaptar ao padrão de comportamento do reasonable man, adapta-se esse de padrão de 
conduta, tornando-o mais flexível para as circunstâncias dessas pessoas, para que possam ser responsáveis por danos pessoais ou patrimoniais causados a terceiros. ${ }^{6}$

Cremos que essa fórmula intermediária se mostra a mais coerente no intuito de sopesar autonomia e cuidado como balizas do modelo social de deficiência. Por um ângulo, reforça-se a promoção da liberdade, sem prejuízo à esfera existencial da pessoa. Lado outro, imputa-se a ela sanções meramente econômicas, que não comprimem a sua intimidade ou livre desenvolvimento da personalidade. Por fim, mirando agora na pessoa do ofendido, não haverá prejuízo à dinâmica da função compensatória da responsabilidade civil, direcionada à passagem dos prejuízos da esfera vítima para a do autor do fato danoso, pois incidirá legítima justificativa para o juiz verificar se caberá ou não mitigar os danos e, caso positivo, em qual medida.

\section{A responsabilidade civil pela guarda de fato de pessoas maiores com deficiência}

\subsection{Compreendendo a guarda de fato}

Antes de adentrar à questão da responsabilidade civil, é necessário compreender o conceito da "guarda de fato", sobremaneira em face do contraste entre a indefinição legal e a realidade de um fato tão frequente em caso de menores de idade, maiores de idade com incapacidade natural e, principalmente, idosos com doenças senis. Pode-se definir a guarda de fato como "uma situação em que uma pessoa se encarrega do cuidado de outra que necessita de proteção, sem intervenção administrativa ou judicial, e à margem da existência de um dever legal". ${ }^{7}$ As pessoas submetidas à guarda de fato costumam ser maiores em situações de dependência, que carecem de condições materiais e afetivas e que se integram em uma família sem que existam vínculos de parentesco, ou que por sua condição psíquica ou intelectual poderiam estar incapacitadas, mas não estão.

\footnotetext{
${ }^{6}$ Como bem adverte Maria Cristina Berenguer Albaladejo, "juzgar la responsabilidad de las personas con discapacidad prescindiendo de sus concretas aptitudes psíquicas sería injusto y muy gravoso para este colectivo porque su conducta se estaría valorando conforme a un estándar de diligencia inalcanzable para ellos”. In: Responsabilidad civil de la persona mayor con discapacidad. Madrid: Editorial Reus, 2017, p. 45.

7 AlBALADEJO, Maria Cristina Berenguer. Responsabilidad civil de la persona mayor con discapacidad. Madrid: Editorial Reus, 2017, p. 60.
} 
Em termos gerais, a guarda de fato existirá desde que uma pessoa - natural ou jurídica -, sem ter atribuídas faculdades de curatela ou tutela, encarrega-se voluntariamente de outra, seja criança, adulto ou idoso com deficiência, que se encontra em situação de desamparo. Pode-se dizer que a guarda de fato é uma instituição tão antiga como o ser humano, pois sempre existiram pessoas que espontaneamente cuidam de indivíduos desvalidos, sem obrigação para tanto. Talvez, seja a figura mais utilizada na prática por serem os familiares ou amigos íntimos de pessoas com deficiência não submetidas a procedimento de modificação de capacidade de agir que normalmente assumirão o cuidado delas. ${ }^{8}$

Se nos centrarmos na situação do menor de idade, a guarda de fato se exercerá normalmente pelos avós, vizinhos ou amigos dos pais. Situação que se verificará quando não existirem pais ou tutores que destes se encarreguem, ou quando existirem mas não assumirem a responsabilidade parental ou as funções designadas por lei. No tocante às pessoas maiores com deficiência mental ou intelectual (o que nos interessa especialmente), os guardiões costumam ser pais, irmãos, filhos e parentes próximos. A guarda de fato também poderá recair sobre uma instituição quando essas pessoas ingressem em centros habilitados para o exercício dessa função. Em qualquer caso, ela se desenvolve com naturalidade, sem conflitos ou litígios, proporcionando à pessoa com deficiência a atenção e apoio que necessita. A final, sabemos que para proteger, não é preciso incapacitar alguém previamente.

Podemos dizer que existem três formas de proteção e promoção de direitos fundamentais da pessoa com deficiência mental ou psíquica: a) curatela; b) tomada de decisão apoiada; c) guarda de fato. Não obstante as duas primeiras sejam modelos jurídicos reconhecidos na legislação civil brasileira, apartam-se em sua estrutura e função: a curatela é uma medida de incapacitação judicial de pessoas desprovidas de autodeterminação (art. 4 $4^{\circ}$, III, CC), cuja função precípua é a de proteção de quem necessita de representação ou assistência para a prática dos atos da vida civil. Em contrapartida, a TDA é uma medida de apoio a alguém que mantem a capacidade plena,

\footnotetext{
${ }^{8}$ ALGUACIL, Maria José García. Protección Jurídica de las personas con discapacidad. Madrid, Reus: 2017, p. 170 .
} 
sendo a sua funcionalidade primordialmente localizada na promoção, pelos apoiadores, dos espaços de autonomia da pessoa com deficiência em situação de vulnerabilidade. ${ }^{9}$

Em contrapartida, a guarda de fato surge como tertium genus, consistindo em uma atuação imediata sobre pessoas maiores cuja capacidade não tenha sido judicialmente modificada, mas em tese deveriam ter sido curateladas por se encontrarem em situação de ausência de autogoverno ou necessitem de proteção por terem limitações em suas faculdades volitivas que as coloquem em situação de risco, sem que tenham sido submetidas à tomada de decisão apoiada. Considerando que o Código Civil prescindiu de uma tipificação ou caracterização legal da figura da guarda de fato, podemos afirmar que o guardador de fato será toda pessoa que custodie ou atenda a alguém necessitado de proteção, sem possuir título legal que o habilite para tanto. Cuida-se de uma situação de atenção prolongada no tempo, ocupando uma posição de centralidade real entre as formas em que são atendidas as pessoas afetadas por uma deficiência.

Com efeito, a nossa opção pela terminologia "guarda de fato", ao invés de expressões como "custódia de fato" ou "cuidado de fato", não se deve ao precipitado apelo a um "transplante jurídico"10 do direito espanhol. A diligente importação de conceitos jurídicos demanda uma aferição de seus contornos no sistema jurídico do país receptor. Partimos, portanto, do art. 1.590 do Código Civil, ao dispor que: "As disposições relativas à guarda e prestação de alimentos aos filhos menores estendem-se aos maiores incapazes". Evidentemente o dispositivo não alude aos "maiores incapacitados" - eis que cabe ao curador a função legal de guardião, judicialmente outorgada - porém aos maiores naturalmente incapazes, cuja curatela não foi formalizada. Tal conclusão se embasa na própria topografia da norma, situada no

\footnotetext{
${ }^{9}$ Justamente pelas distinções estrutural e funcional entre os dois modelos jurídicos, dispôs o Enunciado 640 do CJF que: "A tomada de decisão apoiada não é cabível, se a condição da pessoa exigir aplicação da curatela".

${ }^{10}$ O Conceito de "transplante legal" é atribuído ao jurista Alan Watson, em seu insight de que o direito privado de vários países é significativamente baseado na recepção do direito romano e que, contemporaneamente, esse fenômeno não se ocorre na importação de uma determinada norma ou regramento jurídico, como também se estende ao âmbito de decisões estrangeiras ou doutrinas de direito comparado, com o objetivo de transferir ideias específicas, como, ilustrativamente, transplantes que objetivem liberalizar o direito de família em termos de introdução de divórcio sem culpa ou uniões do mesmo sexo. In: Legal transplants: An approach to comparative law. 2. ed. Athens, GA: University of Georgia Press, 1993, p. 8.
} 
Capítulo XI, do Título I do Livro do Direito e Família, dedicado à "Proteção da pessoa dos filhos"

Assim, a interpretação sistemática do art. 1.590 conduz ao alargamento do conceito de guarda, no trato das relações verticais entre ascendentes e descendentes, sejam os vínculos biológicos, afetivos ou registrais. No conceito lato sensu de guarda como uma obrigação imposta a alguém de ter vigilância e zelo para conservação do bem, de coisas ou pessoas, que estão sob sua responsabilidade, podemos realizar um recorte stricto sensu para a guarda do direito de família, como um conceito dinâmico e poroso, que nos últimos anos se ampliou para acolher as formas de guarda unilateral, alternada, compartilhada (ou conjunta) e nidal, sendo comum a essas denominações a ideia da convivência familiar.

Nessa constante ressignificação funcional do conceito de guarda, merece enfoque uma nova etapa, agora tendo como destinatários não apenas os filhos, mas aquelas pessoas cuja vulnerabilidade se potencializa pela persistência de uma deficiência psíquica ou intelectual congênita ou pela perda ou deterioração da autodeterminação na idade adulta ou na velhice. Ao alargar o conceito de responsabilidade parental, objetivando a persistência da convivência familiar com os filhos adultos incapazes, o art. 1.590 do Código Civil não apenas faz implícita menção aos genitores - protagonistas naturais da função de guardiões - mas faculta a compreensão, tal como já ventilou a doutrina, de ser o guardião "o pai ou a mãe, ambos, ou mesmo terceiros, que detêm a guarda fática e jurídica deles". ${ }^{11}$

O Estatuto da Criança e do Adolescente transcende a noção puramente civilista de "guarda", referindo-se a ela como uma das formas de colocação de crianças e adolescentes em famílias substitutas (art. 28, Lei 8.069/1990), cabendo ao detentor da guarda a obrigação de prestação de assistência material, moral e educacional, destinando-se a "regularizar a posse de fato" do menor que se encontra em situação irregular $\left(\S 1^{\circ}\right.$, art. 33). Note-se que o ECA estabelece um recorte entre guarda de fato e guarda de direito na seara das relações entre guardiões e crianças e adolescentes que não se encontrem sob o cuidado da família natural.

\footnotetext{
${ }^{11}$ PEREIRA, Rodrigo da Cunha Pereira. Dicionário de direito de família e sucessões. São Paulo: Saraiva, 2017, p. 366.
} 
Essa adaptabilidade do modelo jurídico da guarda impele-nos a dilatar os seus contornos ao campo dos adultos com deficiência, privados total ou parcialmente de autogoverno e cuja vigilância e assistência é produzida fora dos espaços jurídicos destinados à modulação de capacidade ou à tomada de decisão apoiada. Por conseguinte, nos planos estrutural e funcional a guarda de fato tanto poderá mimetizar a curatela como a TDA, recaindo sobre um heterogêneo universo de pessoas com ausência ou déficit de capacidade natural e que não são curateladas ou tampouco apoiadas. Em casos mais graves, sob o ângulo jurídico a pessoa deveria estar curatelada e, em outras situações, bastaria a realização do negócio jurídico de apoio.

Em nenhum momento a CDPD ou o legislador equiparam a guarda de fato à figura do curador ou do apoiador, basicamente porque aquelas são instituições reconhecidas pela autoridade judicial, enquanto que a guarda de fato se caracteriza pelo desconhecimento da instituição por autoridades e organismos encarregados de proteção de pessoas vulneráveis. Contudo, essa circunstância não reflete a vida em sociedade, pois enquanto no âmbito jurídico a sentença de incapacitação tradicionalmente se considerava um mecanismo idôneo de proteção à pessoa com deficiência mental ou intelectual, socialmente sempre foi a guarda de fato a medida preferida pelas famílias, relutantes em submeter um ente querido a um procedimento de modulação de capacidade.

Tirando a hipótese de menores (cuja responsabilidade objetiva é expressa para pais e tutores - 932, I, c/c 933 CC) e de maiores já curatelados (cuja responsabilidade objetiva é expressa para os curadores - 932, II, c/c 933 CC), merece enfoque a guarda de fato como uma atuação imediata sobre pessoas maiores cuja capacidade não tenha sido judicialmente modificada, mas em tese deveriam ter sido curateladas por se encontrarem em situação de ausência de autogoverno a teor do art. $4^{\circ}$, III, do Código Civil (o incapaz natural), ou mesmo daquelas pessoas maiores cuja capacidade é plena, mantendo resíduos de autodeterminação que impedem a incapacitação, mas que necessitem de proteção pessoal e/ou patrimonial por terem limitações em suas faculdades intelectivas e volitivas que as coloquem em situação de risco, sem que tenham sido submetidas à tomada de decisão apoiada. Finalmente, haverá guarda de fato 
quando a pessoa for curatelada, mas o curador negligencie o exercício das suas funções. $^{12}$

Esta definição ampla permite que sejam considerados guardadores de fato tanto pessoas naturais (de forma espontânea ou como cuidadores profissionais) como pessoas jurídicas, tais como clínicas especializadas ou centros de residência para terceira idade, naqueles casos em que o interno se encontre em situação de necessidade pela inexistência de pessoas que se encarreguem deles ou pela desatenção dos guardiões legais. A residência ou o seu diretor sempre serão meros garantes contratuais de deveres de cuidado e atenção personalizados, contando com seguros de responsabilidade civil para cobrir possíveis danos causados pelos internos. Todavia, a condição especial da guarda legal dependerá da constatação da situação concreta de desamparo da pessoa que lá se encontra.

Ademais, pode-se cogitar de uma guarda de fato em sentido estrito (quando não há qualquer vínculo legal entre o cuidador e o cuidado) e uma guarda de fato lato sensu, que alcança uma juridicidade em certa medida, pois reconhecida pela autoridade judicial e sujeita a medidas de controle e vigilância. Justamente por se tratar a guarda de fato de um dos instrumentos protetivos que mais se concilia com os fins da Convenção de Direitos da Pessoa com Deficiência, a intervenção da autoridade judicial se produzirá no momento em que tenha conhecimento das circunstâncias concretas. Todavia, as medidas que adotará a partir desse momento não se passarão no interno de um procedimento de modificação de capacidade. O Ministério Público não demandará automaticamente a incapacitação ou promoverá a tomada de decisão apoiada (medida que só poderá ser iniciada pelo próprio interessado), ${ }^{13}$ se comprovado que, nas circunstâncias do caso, a guarda de fato parece ser a instituição mais adequada para tutelar os interesses daquela pessoa. O melhor caminho para o magistrado que venha a ter conhecimento de uma guarda de fato que funcione a contento será a outorga ao guardião de faculdades já

\footnotetext{
12 Além da guarda de fato de menores, Maria Cristina Berenguer Albaladejo identifica três situações em que se aplica a guarda de fato em prol de adultos: a) aquelas cuja capacidade tenha sido modulada judicialmente; b) aquelas cuja capacidade não tenha sida modulada mas estejam incursas em uma causa para isso; c) aquelas cuja capacidade não tenha sido modificada, não estão incursas em causa para isso, mas necessitam com uma certa permanência de proteção patrimonial ou pessoal por terem limitadas as suas faculdades intelectivas e volitivas. In: Responsabilidad civil de la persona mayor con discapacidad. Madrid: Editorial Reus, 2017, p. 62.

${ }^{13}$ Estipula o Enunciado 639 CJF: "A opção pela tomada de decisão apoiada é de legitimidade exclusiva da pessoa com deficiência A pessoa que requer o apoio pode manifestar, antecipadamente, sua vontade de que um ou ambos os apoiadores se tornem, em caso de curatela, seus curadores".
} 
previstas para a tutela e curatela, como uma forma de agilizar trâmites e favorecer os interesses da pessoa sob a guarda. Não se trata de conceder um mandato ilimitado ao guardião, porém um reconhecimento da juridicidade da guarda com imposição de limites de atuação sob medida, conforme a concretude do caso.

Porém, para tanto, requer-se uma inovação legislativa que possa alçar aos planos da validade e eficácia os atos praticados pelo guardião de fato que redundam em utilidade à pessoa com deficiência, convertendo-a em uma forma de representação legal que torne efetiva a proteção e salvaguarda dos seus interesses, sem a necessidade de se socorrer de uma sentença de curatela em casos em que o indivíduo preserve resíduos de autogoverno. ${ }^{14}$ Enquanto a legislação civil e processual não for aprimorada e o fato jurídico da guarda de fato de pessoas com deficiência se mantiver periférico ao direito, somente sobejará o recurso ao modelo da gestão de negócios para se conferir póseficácia aos atos praticados pelo guardião de fato quando revertam em utilidade/proveito da pessoa vulnerável. ${ }^{15}$

Cumpre recordar que, em seu dia a dia, a pessoa maior com deficiência psíquica despida de representação terá a possibilidade de realizar uma atuação pessoal juridicamente válida na medida em que possua capacidade natural de se autodeterminar no momento em que atuou. Isto é, a pessoa não curatelada em tais circunstâncias possuirá uma capacidade formal, mas a eficácia real de seus atos dependerá daquilo que a capacidade natural the permita fazer. A evidente distinção consiste em que há uma

\footnotetext{
${ }^{14} \mathrm{Na}$ Espanha, recentes reformas legislativas substantivaram e procedimentalizaram a guarda de fato. Primeiramente, o art. 303 do CC, foi reformado pela Lei 26/2015, dispondo que "Cuando la autoridad judicial tenga conocimiento de la existencia de un guardador de hecho podrá requerirle para que la informe de la situación de la persona y los bienes del menor, o de la persona que pudiera precisar de una institución de apoyo, y de su actuación en relación a los mismos, pudendo establecer asimismo las medidas de control y vigilancia que considere oportunas. Cautelarmente, mientras se mantenga la situación de guarda de hecho y hasta que se constituya la medida de protección adecuada, si procederá, se podrán otorgar judicialmente facultades tutelares a los guardadores". Na sequência, o art. 52 da Lei de Jurisdição Voluntária estabelece um estatuto procedimental para a guarda de fato, nos seguintes termos: “ A instancia del Ministerio Fiscal, del sometido a guarda o de cualquiera que tenga un interés legítimo, el juez que tenga conocimiento de la existencia de un guardador de hecho podrá requerirle para que la informe de la situación de la persona y bienes del menor o de la persona con capacidad modificada judicialmente que hubiere de estarlo y de su actuación en relación con los mismos. 2. El juez podrá establecer las medidas de control y vigilancia que estime oportunas, sin perjuicio de promover expediente para la constitución de la tutela o curatela. Tales medidas se adoptarán, previa comparecencia, citando a la persona a quien afecte la guarda de hecho, al guardador y al Ministerio Fiscal.

${ }^{15}$ Art. 861 do Código Civil: "Aquele que, sem autorização do interessado, intervém na gestão de negócio alheio, dirigi-lo-á segundo o interesse e a vontade presumível de seu dono, ficando responsável a este e às pessoas com que tratar".
} 
presunção de invalidade dos atos praticados pela pessoa curatelada sem o seu curador (o registro civil facilmente comprovará), enquanto que na ausência do devido processo legal, o interessado terá que provar a falta ou insuficiência de capacidade natural da pessoa com deficiência ao tempo da prática do ato pontualmente inquinado como inválido. Evidente, isso gerará reflexos, como a própria discussão sobre a boa fé daquele que com ele contratou. Mais grave, há o risco real de uma paralisia generalizada da esfera jurídica da pessoa sob a guarda de fato, se somarmos a sua eventual falta de capacidade natural, com a ausência de legitimação do guardião para atuar em seu nome, tudo isso associado ao receio de terceiros em realizar atos jurídicos com uma pessoa com deficiência psíquica em tais circunstâncias.

O fundamental é compreender que, como um fato jurídico, a guarda de fato não consiste em uma instituição legal, porém em uma situação de fato que o direito toma em consideração para a produção de determinados efeitos. Assim, quando eventualmente ela se tornar objeto de regulação legal (sujeitos, requisitos, conteúdo, efeitos e extinção), poderá até mesmo conservar a nomenclatura, mas, especificamente quando o cuidado recai sobre pessoas maiores com deficiência psíquica, culminará por alterar a sua natureza, tornando-se um novo modelo jurídico de guarda, uma espécie de "guarda de direito" sem prévia incapacitação, ou uma espécie de "curatela light". Em outros termos, a guarda de fato se converte em uma situação transitória, cujo destino inexorável será o de desembocar em uma guarda legal. Todavia, caso essa guarda de fato institucionalizada demande uma prévia avaliação formal da capacidade natural da pessoa com deficiência e a nomeação judicial do guardião, ao fim e ao cabo teríamos um modelo jurídico parelho à curatela, apenas com a distinção do nomen juris. ${ }^{16}$

Enquanto exerce a guarda de fato à revelia do direito, sem qualquer forma de legitimação da posição em que atue, o guardião estará privado de adotar medidas formais que redundem em benefício e interesse de uma pessoa maior com deficiência. Esse dado não é necessariamente negativo, pois cuidados básicos já são suficientes na maior parte dos casos em que a pessoa sob guarda de fato não possui patrimônio significativo que demande a tomada reiterada de decisões relevantes (que não poderiam

\footnotetext{
${ }^{16}$ Carlos Martinez de Aguirre aponta que a crescente juridificação da guarda de fato turva os contornos legais da figura da guarda de fato, que já não mais será de fato e configurará uma nova instituição legal de guardas, todavia desprovida dos controles derivados do procedimento de incapacitação. In: El tratamiento jurídico de la discapacidad psíquica: reflexiones para una reforma legal. Pamplona: Thomson Reuters Aranzadi, 2014, p. 123.
} 
ser levadas a efeito validamente pelo titular dos bens e por seu guardião). Assim, frequentemente, não será preciso que o guardião desenvolva qualquer atividade juridicamente relevante, fazendo com que a guarda de fato alcance os seus propósitos mesmo à margem do direito. Fundamentalmente, se a guarda de fato funciona adequadamente, não será necessária ou conveniente uma intervenção externa sobre ela, pois, mesmo havendo em tese causa para uma curatela ou uma TDA, inexiste motivo para levar essas medidas adiante, pois as necessidades da pessoa estarão cobertas e, na medida do possível, bem atendidas.

Contudo, ao guardião de fato será interditada a possibilidade de peticionar em organismos oficiais, receber informações, ter acesso à conta bancária, a um notário, enfim, de exercer a aquilo que se considera "administração ordinária" do patrimônio alheio, cingindo-se aos cuidados básicos com a vigilância da pessoa, alimentação e medicação. Ocorre que, na ausência de alternativas - v.g. encontrar uma outra pessoa e encorajar aquele que originariamente se encontrava sob a guarda a iniciar um processo de Tomada de Decisão Apoiada -, a premência da acreditação para a prática de atos (intervenções sanitárias e sociais imediatas, impedimento de esvaziamento patrimonial) muitas vezes conduz o guardião de fato a tomar a iniciativa de se converter em curador, sem que estejam presentes os requisitos legais para a adoção da medida excepcional e extrema de incapacitação.

Quer dizer, por vezes a curatela será uma opção necessária (embora dolorosa) para uma situação a princípio de guarda de fato, quando a pessoa tenha patrimônio significativo e careça completamente de autodeterminação, o que requer atos constantes de representação ou assistência. A titularidade de uma pluralidade de bens também dará ensejo a uma TDA quando a pessoa vulnerável com fragilização de autogoverno requeira coadjuvantes que possam lhe auxiliar em suas constantes decisões econômicas, evitando um descalabro patrimonial. Afora tais casos, como frisamos, em um país de enorme desigualdade socioeconômica como o Brasil, não haverá prejuízo de manter sob a guarda de fato um enorme numero de pessoas que se localizam no limiar do mínimo existencial, quando a atuação do guardião seja positiva sob o aspecto pessoal e afetivo.

Como alternativa entre o binômio legal curatela/TDA e simplesmente manter as coisas como estão (deixar a guarda de fato completamente alijada de controles), impõese a delicada questão de modelar um "estatuto mínimo" de uma guarda de fato, pela 
qual se atribua ao guardião funções e faculdades, sem, contudo, realizar-se uma prévia avaliação formal da capacidade natural da pessoa sob guarda nem um controle judicial sobre a nomeação do guardião. De fato, não teríamos aí uma curatela, tampouco uma tomada de decisão apoiada, o que poderia gerar celeumas, pois qualquer intervenção legislativa sobre a guarda de fato implicará em um fator de heteronomia a limitar as possibilidades de atuação da pessoa com deficiência psíquica. Afinal, sem um controle judicial sobre a capacidade real de entender e querer da pessoa sob guarda de fato e da mensuração da idoneidade do guardião que atuará em seu nome, instala-se uma insegurança sobre a proteção adequada que se destine à pessoa com deficiência.

No estágio atual do direito brasileiro, nada existe em termos de intervenção do ordenamento sobre a guarda de fato. Ocorre que eventualmente pessoas com deficiência psíquicas alijadas do sistema binário da curatela/TDA necessitarão da intervenção formal por parte do guardião, mesmo em aspectos envolvendo atos sanitários ou obtenção de informações administrativas. Essa acreditação poderá ser obtida por meio de uma ata notarial. De acordo com o art. 384 do CPC/15: "A existência e o modo de existir de algum fato podem ser atestados ou documentados, a requerimento do interessado, mediante ata lavrada por tabelião". Tratando-se a guarda de fato de um fato notório sobre o qual se fundam direitos e se legitimam situações patrimoniais e existenciais com transcendência jurídica, a ata notarial será um meio típico de prova com presunção de veracidade e fé pública. Em linhas gerais, a ata notarial é um instrumento público, lavrado por tabelião de notas (Lei Federal 8.935/1994, art. $7^{\circ}$, III) a requerimento de pessoa interessada, que se destina a atestar (por meio dos sentidos do próprio notário) e documentar a existência ou o modo de existir de algum fato jurídico, notadamente com vistas à formação de prova pré-constituída para auxiliar o autor na obtenção de tutela provisória requerida liminarmente. ${ }^{17}$

Outra via de acreditação do guardião de fato será o procedimento de jurisdição voluntária, atividade de natureza jurisdicional exercida pelo Estado em processos cujas pretensões consistem na integração e aperfeiçoamento de negócios jurídicos que

\footnotetext{
${ }^{17}$ Nesse sentido ensina Daniel Amorim Assumpção Neves que "outra hipótese em que vislumbro grande valia para a ata notarial é a circunstância de o autor precisar de tutela provisória liminarmente, mas não ter prova documental que corrobore as suas alegações. Sendo as declarações do tabelião constantes de ata notarial dotadas de fé pública, há uma presunção de veracidade suficiente para convencer o juiz em grau de cognição sumária, da veracidade das alegações de fato feitas pelo autor em sua petição inicial”. In: Código de Processo Civil Comentado. Salvador: Juspodivm, 2017, p. 680.
} 
dependem do pronunciamento jurisdicional. Por essa via despida de litigiosidade, obtém-se a declaração judicial da existência da guarda sobre a pessoa com deficiência, podendo o magistrado se valer de um juízo de equidade e, alheio à legalidade estrita, ditar as medidas convenientes e oportunas (parágrafo único do art. 723 do CPC/15) a fim de evitar riscos e/ou prejuízos patrimoniais ao indivíduo vulnerável.

Nada obstante, o problema se encontrará nos limites da atuação do guardião de fato. Não lhe será facultado o exercício de atos que excedam o usual e culminem por repercutir na esfera existencial da pessoa com deficiência. Se na própria curatela a intervenção na esfera de intimidade do curatelado somente se justificará excepcionalmente (art. 749, CPC/15), não vemos a menor possibilidade de uma decisão no âmbito de jurisdição voluntária que legitime o guardião de fato a intervir em aspectos da vida pessoal, sexual e sanitária que não impliquem em riscos iminentes à vida ou à integridade da pessoa com deficiência, considerando-se ainda que o indivíduo preserva alguma aptidão de autodeterminação e interação social.

Por fim, a par da trilogia curatela/TDA/guarda de fato, cumpre lembrar que, no limite, existem pessoas formalmente incapacitadas, porém materialmente desprotegidas. A situação de desamparo resulta do incumprimento ou inadequado exercício dos deveres que incumbem legalmente ao curador, resultando em real privação da indispensável assistência material ou moral à pessoa curatelada, ${ }^{18}$ até mesmo em razão da inexistência de uma outra pessoa que, em caráter substitutivo, possa exercer a função de guardião de fato (não apena parentes, amigos, como um centro psiquiátrico ou uma residência de idosos).

Em razão da identidade funcional dos modelos jurídicos, os arts 1.774 e 1.781 do Código Civil proclamam que as regras do exercício da tutela (arts 1740 a 1752) se aplicam à curatela. Especificamente naquilo que nos interessa, de acordo com os arts 1.740 e 1741 do $\mathrm{CC}$, “incumbe ao tutor, quanto à pessoa do menor: I - dirigir-lhe a educação, defendê-lo e prestar-lhe alimentos, conforme os seus haveres e condição; II -

\footnotetext{
${ }^{18}$ María Victoria Mayor del Hoyo explica que o conceito jurídico indeterminado “, assistência moral ou material" remete a um standard de trato com a pessoa. A desatenção material é menos complicada em sua delimitação teórica e na própria identificação prática em comparação com a desatenção moral. No amplo conceito de desatenção moral subsumam-se situações variadas como insultos, ameaças, castigos, abusos laborais, isolamentos injustificados e omissão do dever de coadjuvar, recuperar e integrar o curatelado socialmente, condutas que impedem a melhora da qualidade de vida da pessoa curatelada. In: Un nuevo modelo de protección de las personas con discapacidad. Pamplona: Thomson Reuters - Aranzadi, 2014, p. 82.
} 
reclamar do juiz que providencie, como houver por bem, quando o menor haja mister correção; III - adimplir os demais deveres que normalmente cabem aos pais, ouvida a opinião do menor, se este já contar doze anos de idade. Art. 1.741. Incumbe ao tutor, sob a inspeção do juiz, administrar os bens do tutelado, em proveito deste, cumprindo seus deveres com zelo e boa-fé". Adaptando-se as referidas atribuições tutelares ao universo da curatela de pessoas maiores com modulação de capacidade, temos que se afigura ambiência disfuncional quando o curador objetivamente não performa parâmetros mínimos de atenção a deveres patrimoniais e pessoais, exemplificados nos arts. 1.747 e 1.748 do CC. ${ }^{19}$

Nas situações anômalas de ineficácia da instituição originalmente estruturada pelo legislador (curatela) em benefício da pessoa incapacitada, o ordenamento deve instituir mecanismos que lhe ofereçam uma proteção funcional. A par da já positivada possibilidade de remoção do curador pelo Ministério Público, ${ }^{20}$ de lege ferenda, diante da constatação concreta de um caso de desassistência fática, cremos que o Estado terá que intervir a fim de instituir uma curatela administrativa da pessoa incapacitada a ser fiscalizada pelo Ministério Público e modulada conforme os termos demarcados pela sentença de curatela e que durará indefinidamente até que a pessoa recupere o autogoverno, a menos que, em algum momento, o curador originário recupere a sua legitimidade para proteger a pessoa que remanesce desprovida de autodeterminação ou então seja identificado um novo sujeito que possa idoneamente exercer a função de curador.

Prosseguindo, é possível cogitar de situações em que a pessoa incapacitada não está desamparada, mas o curador se encontra em um cenário de dificuldades que fatalmente resultará em desassistência. Assim, tal como previsto para a tutela (por

\footnotetext{
${ }^{19}$ Art. 1.747CC/02: "Compete mais ao tutor: I - representar o menor, até os dezesseis anos, nos atos da vida civil, e assisti-lo, após essa idade, nos atos em que for parte; II - receber as rendas e pensões do menor, e as quantias a ele devidas; III - fazer-lhe as despesas de subsistência e educação, bem como as de administração, conservação e melhoramentos de seus bens; IV - alienar os bens do menor destinados a venda; V - promover-lhe, mediante preço conveniente, o arrendamento de bens de raiz; Art. 1.748. Compete também ao tutor, com autorização do juiz: I - pagar as dívidas do menor; II - aceitar por ele heranças, legados ou doações, ainda que com encargos; III - transigir; IV - vender-lhe os bens móveis, cuja conservação não convier, e os imóveis nos casos em que for permitido; $\mathrm{V}$ - propor em juízo as ações, ou nelas assistir o menor, e promover todas as diligências a bem deste, assim como defendê-lo nos pleitos contra ele movidos".

${ }^{20}$ Art. $761 \mathrm{CPC} / 15$ : "Incumbe ao Ministério Público ou a quem tenha legítimo interesse requerer, nos casos previstos em lei, a remoção do tutor ou do curador”.
} 
extensão do referido art. 1.774 do Código Civil), no art. 1.764, para além da hipótese de remoção - que requer um desamparo real e atual - cessarão as funções do tutor "ao sobrevir escusa legítima" (inciso II). Desta maneira, o próprio curador poderá pleitear a resolução judicial da curatela, tendo em vista a demonstração inequívoca de um iminente desamparo, pela impossibilidade de manutenção da necessária assistência pessoal e econômica à pessoa incapacitada. A causa da "escusa legítima" não poderá obviamente ser um fato voluntário, mas uma situação fortuita ou uma conduta culposa do próprio curador (v.g. alcoolismo).

Não defendemos de forma alguma a extensão de uma curatela administrativa em benefício de qualquer pessoa em tese tida como "incapaz" - mesmo quando desamparada, porém somente em prol dos "incapacitados". Por um lado, qualquer pessoa carecedora de capacidade natural de autogoverno é incapaz, mesmo quando não tenha sido submetida a um processo formal de curatela que ao final promova a sua incapacitação. Por outro lado, o fato de ser incapaz por si só não autoriza que o Estado promova a sua incapacitação à revelia do devido processo legal. $\mathrm{O}$ art. 12.4 da CDPD instituiu salvaguardas que, dentre outras, asseguram uma presunção de capacidade de qualquer pessoa, inibindo ingerências em sua capacidade ou qualquer forma de abuso em matéria de direitos humanos. É preciso estar incapacitado judicialmente e faticamente desassistido para que se cogite de uma intervenção extrema pela via da curatela administrativa.

Isso não impede que, chegando ao conhecimento do Ministério Público a notícia da existência de pessoa com incapacidade natural em estado de desamparo - portanto, desprovida de um guardião fático -, promova a ação de curatela e tutela de urgência (v.g. nomeação de curador provisório) que confira proteção imediata a quem se encontre não só privado de autodeterminação como também de assistência. ${ }^{21}$

A proposta desenvolvida nos tópicos precedentes se dá com base na percepção do que temos atualmente positivado. Conforme o art. 1.774 do CC/02, aplicam-se à curatela as disposições concernentes à tutela. Especificamente quanto à tutela, a única norma que versa sobre a hipótese de desamparo de menores é o art. 1.734 do Código

\footnotetext{
${ }^{21}$ Art. 748 CPC/15: “O Ministério Público só promoverá interdição em caso de doença mental grave: I se as pessoas designadas nos incisos I, II e III do art. 747 não existirem ou não promoverem a interdição; II - se, existindo, forem incapazes as pessoas mencionadas nos incisos I e II do art. 747”.
} 
Civil, dispondo que: "As crianças e os adolescentes cujos pais forem desconhecidos, falecidos ou que tiverem sido suspensos ou destituídos do poder familiar terão tutores nomeados pelo Juiz ou serão incluídos em programa de colocação familiar, na forma prevista pela Lei $\mathrm{n}^{\mathrm{o}}$ 8.069, de 13 de julho de 1990 - Estatuto da Criança e do Adolescente". Se resgatarmos essa norma ao âmbito da curatela, entenderemos que a remoção do curador será requisito sine qua non para a inclusão de uma pessoa incapacitada em um programa de "colocação familiar". Porém, mesmo que o Ministério Público se incumba desse mister, a colocação em família substituta é uma medida que ainda não foi normatizada (ou sequer pensada) para pessoas curateladas em situação de vulnerabilidade.

A colocação familiar ou acolhimento familiar não apenas não existe no âmbito da incapacidade como não foi desenhada para ela. Pelo contrário, é mecanismo ótimo para fazer frente às necessidades de tutela de menores em situação de risco ou efetiva desproteção. $^{22}$ As distinções entre menores e incapacitados são evidentes e, teoricamente, parece mais simples encontrar acolhedores para crianças do que para maiores desprovidos de autodeterminação, até porque a inserção em família substituta está orientada a uma futura adoção ou, mesmo que assim não o seja, a casais que desejam ter a experiência de criar crianças, mesmo que temporariamente.

Todavia, a lacuna legislativa não nos impede de lembrar que o próprio preâmbulo da CDPD (letra $\mathrm{x}$ ) enaltece a família como entidade fundamental da sociedade, sendo que as pessoas com deficiência e seus familiares devem receber a proteção e assistência necessárias para que as famílias possam contribuir para que aquelas gozem de seus direitos plenamente e em igualdade de condições. Realmente, a vida em família com a possibilidade do livre desenvolvimento da personalidade e

\footnotetext{
${ }^{22}$ A Lei 12.010/2009 (que alterou o ECA em diversos de seus dispositivos), enfatizou a necessidade de evitar ao máximo o acolhimento institucional (assim como o afastamento da criança/adolescente de sua família de origem), como fica claro dos princípios que acrescentou ao art. 100, par. único, do ECA, como o da "responsabilidade parental" (inciso IX, do citado dispositivo) e da "prevalência da família" (inciso X, do mesmo dispositivo). Também enfatizou, por exemplo, que o Conselho Tutelar não possui atribuição de promover o afastamento da criança ou adolescente (ainda que em situação de risco) de sua família de origem, fazendo constar do art. 136. par. único, do ECA que, caso o Colegiado do Conselho Tutelar entenda necessário tal afastamento, comunicará o fato ao MP, fornecendo elementos que permitam que este ingresse com demanda de cunho necessariamente contencioso, em que fique claro a real necessidade da medida extrema. Tanto o afastamento da criança/adolescente do convívio familiar quanto sua colocação em família substituta, ainda que seja esta integrante da "família extensa" (parentes com relação de proximidade e afinidade/afetividade), é de competência exclusiva da autoridade judiciária, podendo o Conselho Tutelar, quando muito, em colaboração com o Juiz, tentar localizar parentes em condições de receber crianças/adolescentes sob guarda/tutela/adoção.
} 
respeito às vontades e preferências da pessoa com deficiência mental ou intelectual em seus resíduos de autonomia é um dado fundamental para que haja a ampliação do conceito de família substituta para o acolhimento de pessoas curateladas que não dispõem de cuidado em seu entorno familiar originário, encontrando-se em situação de desproteção. Uma curatela - ou na falta dela o amparo por centros assistenciais consiste em medida que não oferece uma vida em família. O curador não possui a obrigação de ter o curatelado em sua companhia, como da mesma forma o diretor de um centro residencial ou instituição médica não terá entre os seus deveres de guarda, qualquer um que se relacione à doação de afeto.

O conteúdo da colocação familiar se assemelharia ao aspecto pessoal da curatela, tendo os acolhedores notoriamente de velar pela companhia, alimentação, educação e formação integral do curatelado (tal como ocorre com os menores) com a peculiaridade de que aos deveres ora descritos, acrescer-se-á a obrigação de proporcionar cuidados especiais que a especificidade da curatela impõe, promover a sua recuperação e reinserção em sociedade. Rememore-se que tal e qual a indispensabilidade do consentimento do adolescente (a partir de 12 anos) ${ }^{23}$ para a prática do ato jurídico, o mesmo se diga quanto à obtenção da anuência da pessoa incapacitada, quando a sua deficiência ainda lhe permita um discernimento suficiente para fazer da família substituta a família desejada, potencializando-se o respeito a sua vontade e preferências, como requer a CDPD. ${ }^{24}$

Basicamente, constituir-se-ia uma nova entidade familiar em substituição ao núcleo originário do incapacitado, em um lar funcional, eis que vocacionado para proteger e promover direitos fundamentais da pessoa com deficiência, fornecer-lhe afeto e plena participação na vida comunitária, de forma similar a qualquer outra manifestação biológica ou socioafetiva de família. Neste design, na falta ou impossibilidade da própria família extensa da pessoa curatelada, cremos que os acolhedores não se limitariam a um par conjugal (seja ele proveniente do matrimônio,

\footnotetext{
${ }^{23}$ Art. 28 da Lei n. 8.069/90: “A colocação em família substituta far-se-á mediante guarda, tutela ou adoção, independentemente da situação jurídica da criança ou adolescente, nos termos desta Lei. § $1^{0}$ Sempre que possível, a criança ou o adolescente será previamente ouvido por equipe interprofissional, respeitado seu estágio de desenvolvimento e grau de compreensão sobre as implicações da medida, e terá sua opinião devidamente consideradaß $2^{\underline{0}}$ Tratando-se de maior de 12 (doze) anos de idade, será necessário seu consentimento, colhido em audiência.(Redação dada pela Lei no 12.010 , de 2009)".

${ }^{24}$ HOYO, Maria Victoria Mayor del. Un nuevo modelo de protección de las personas con discapacidad. Pamplona: Thomson Reuters - Aranzadi, 2014, p. 113.
} 
união estável ou homoafetiva) mas a qualquer dupla vinculada por um parentesco (mãe e avó, irmãos) ou mesmo um par de amigos que queiram assumir a função de familiares substitutos, com todas as suas responsabilidades.

\subsection{Guarda de fato e responsabilidade civil}

Em sentido mais amplo, há de se indagar não apenas se pais cuidadores se responsabilizam civilmente por danos causados por filhos maiores - ou, como demonstra a experiência, também irmãos, filhos e parentes "guardiões" -, mas se, em face do silêncio do Código Civil, qualquer pessoa que venha a exercer a guarda de fato sobre indivíduos maiores com deficiência mental ou psíquica - sejam eles curatelados ou não curatelados - assumirá a responsabilidade por danos causados a essas pessoas contra terceiros. Em adendo, questiona-se sobre a possibilidade de imputação pessoal de danos a uma pessoa maior incapaz (porém não incapacitada) por danos praticados contra terceiros. A necessidade de um norte se torna mais aguda à medida que a demografia brasileira aponta para o envelhecimento da população ${ }^{25}$ e o consequente aumento de doenças crônicas degenerativas e incapacitantes.

O fato de que a pessoa maior com deficiência possa ser declarada pessoalmente responsável por seus comportamentos danosos não exclui a responsabilidade de seus guardiões. A dificuldade consiste em determinar o fundamento desta responsabilidade e o modo pela qual ela deva se articular quando concorra com a responsabilidade do próprio autor do dano, caso tenha ele capacidade de querer e entender ao tempo da prática do fato ilícito. Ademais, será possível cogitar de situações em que coexistam guardiões de fato e de direito, o que por certo ampliará o círculo de responsáveis.

Dispõe o art. 932 do Código Civil que, independente da constatação da responsabilidade do próprio causador do dano por atos comissivos e omissivos próprios,

\footnotetext{
${ }^{25}$ A população brasileira deverá crescer até 2047, quando chegará a 233,2 milhões de pessoas. Nos anos seguintes, ela cairá gradualmente, até os 228,3 milhões em 2060. Essas são algumas das informações da revisão 2018 da Projeção de População do IBGE, que estima demograficamente os padrões de crescimento da população do país, por sexo e idade, ano a ano, até 2060. Em 2060, um quarto da população (25,5\%) deverá ter mais de 65 anos. Nesse mesmo ano, o país teria 67,2 indivíduos com menos de 15 e acima dos 65 anos para cada grupo de 100 pessoas em idade de trabalhar (15 a 64 anos). Extraído de https://agenciadenoticias.ibge.gov.br/agencia-sala-de-imprensa/2013-agencia-denoticias/releases/21837-projecao-da-populacao-2018-numero-de-habitantes-do-pais-deve-parar-decrescer-em-2047, em 13/8/18
} 
impõe-se também a responsabilidade civil indireta por fatos de terceiros em uma série de casos. Assim, estabelece o legislador que os pais são responsáveis pelos filhos menores que estiverem sob sua autoridade e em sua companhia; tutores e curadores, pelos pupilos e curatelados, que se acharem nas mesmas condições; também o empregador se responsabiliza por seus empregados, no exercício do trabalho que lhes competir, ou em razão dele; e, ainda, os donos de hotéis, hospedarias, casas ou estabelecimentos onde se albergue por dinheiro, mesmo para fins de educação, responsabilizam-se pelos seus hóspedes, moradores e educandos. Em suma, não é qualquer pessoa que responde por fatos alheios, devendo existir entre elas uma relação concreta, seja de natureza familiar ou pessoal, empresarial ou educativa. Em comum a esses casos, constata-se uma relação de dependência ou subordinação que origina uma hierarquia e a consequente responsabilidade das referidas pessoas por aqueles que se encontram em dependência. Some-se a isto, o aspecto prático de superação das limitações da responsabilidade individual de pessoas que dificilmente suportariam indenizações, ampliando-se em prol das vítimas o leque de responsáveis, permitindo que possam reclamar em face de pessoas solventes ou cobertas por seguros de responsabilidade civil.

Nada obstante, o art. 932 do Código Civil omite qualquer referência aos guardiões de fato como responsáveis por fato de terceiro. Isto gera duas interpretações colidentes: a primeira, considerando uma hermenêutica restritiva do dispositivo, de forma a manter a sua literalidade e considerar que as hipóteses ali elencadas são numerus clausus, de modo a excluir a guarda de fato; lado outro, uma interpretação ampla e que entenda a enumeração legal como meramente exemplificativa, a ponto de incluir a guarda de fato como uma variação cabível na tutela e curatela, partindo da premissa de que o Código Civil abarca todas as figuras protetivas que envolvam relações de companhia e vigilância mais ou menos estáveis entre pessoas vulneráveis e os seus protetores. A identidade de razões entre as hipóteses de guarda de direito e de fato tornaria possível a aplicação analógica do preceito legal.

Como veremos amiúde, preferimos uma interpretação que responsabilize a pessoa que exerce a guarda de fato pelos danos que a pessoa com deficiência possa causar a terceiros. Ou seja, quem delibere por assumir o cuidado e a assistência de uma pessoa que não pode se autodeterminar completamente por ter reduzida a suas 
faculdades cognitivas e volitivas - independentemente de sua capacidade ter sido ou não modificada judicialmente - terá obrigação de reparar os prejuízos que aquela cause, sendo suficiente que se afirme o vínculo ou nexo de dependência. ${ }^{26} \mathrm{O}$ dever de custódia não só deriva da lei, como também é corolário da voluntária assunção de uma obrigação.

Ao examinar o art. 2.047 do Código Civil Italiano, ${ }^{27}$ que trata da responsabilidade daquele que exerce a "sorveglianza" (vigilância) de um incapaz, Massimo Bianca $^{28}$ explica que o dispositivo abarca as pessoas que não foram interditadas, porém são incapazes de entender e querer, sendo certo que a responsabilidade dos guardiões emerge não apenas de um vínculo jurídico, mas também e uma escolha livremente assumida por um sujeito que, acolhendo outrem em sua esfera pessoal ou familiar, assume pessoalmente a tarefa de prevenir ou impedir que o seu comportamento possa causar dano a outrem.

Outra lacuna a ser preenchida consiste na excepcional responsabilidade equitativa da pessoa inimputável ao tempo da prática do ato danoso, com base no art. 928 do Código Civil. Excluindo a discussão sobre a impossibilidade financeira ou insolvência de pais e curadores - o que remeteria à obrigação de indenizar diretamente ao causador do dano -, há uma segunda hipótese de transladação de prejuízos diretamente para o agente, relativa a "se as pessoas por ele responsáveis não tiverem obrigação de fazê-lo...”.

Ilustra-se com um idoso não submetido a curatela, detentor de vultoso patrimônio, porém sob os cuidados de sua irmã, que, em razão de doença crônica degenerativa, não possuía mínimo discernimento ao tempo em que praticou comportamento antijurídico danoso. Qual seria a solução: atribuir a responsabilidade diretamente ao autor do fato em face da inexistência de um responsável legal ou imputar a obrigação de indenizar ao guardião de fato? Caso a sua irmã fosse considerada como "responsável" em virtude de uma interpretação extensiva da regra do Código Civil,

\footnotetext{
${ }^{26}$ No mesmo sentido, o artigo 6:101 do PETL (Principles of European Tort Law), ao declarar que "a pessoa que tem a custódia de outra, menor ou com deficiência mental, é responsável pelos danos causados por essa pessoa, a menos que o custodiante demonstre que agiu em conformidade ao adequado standard de comportamento de supervisão". O decisivo no preceito é o fato de uma pessoa se encarregar de alguém com deficiência, independente da titularidade formal de uma posição jurídica.

27 "In caso di danno cagionato da persona incapace di intendere o di volere il risarcimento è dovuto da chi è tenuto alla sorveglianza dell'incapace, salvo che provi di non aver potuto impedire il fato"

${ }^{28}$ BIANCA, Massimo. Diritto civile, 5, la responsabilità. Milano: Giuffrè, 2015, p. 702-3.
} 
arcaria ela com os danos apenas diante da inequívoca constatação de sua omissão de dever de cuidado, ou seria considerada objetivamente responsável tal como um curador (art. 933, CC)?

Constata-se que o direito civil brasileiro ignorou as relações informais entre cuidadores e pessoas com deficiência mental ou psíquica, legislando apenas para os incapacitados judicialmente e colocando à margem do direito a maior parte dos fatos jurídicos envolvendo pessoas em situação de vulnerabilidade que se encontram sob a guarda de fato.

\subsection{Responsabilidade civil dos pais como guardiões de fato}

Adultos vulneráveis são pessoas que alcançaram a idade de 18 anos e, por razão de deficiência ou insuficiência em suas faculdades pessoais, não se encontram em posição de proteger os seus interesses pessoais ou patrimoniais, seja de forma temporária ou permanente. Filhos com deficiência são responsabilidade dos pais por toda a vida; $85 \%$ das pessoas com retardo mental vivem com os pais ou sob a sua supervisão, ou num arranjo que permanece comum até que eles se tornem incapazes ou morram. Adultos com deficiência ainda podem exigir atenção na meia-idade, quando outros filhos adultos estão cuidando dos próprios pais. ${ }^{29}$

Em princípio, os pais respondem, perante terceiros, pelos danos causados pelos filhos menores (CC, art. 932, I). Não lhes vale sequer a alegação de que não houve culpa de sua parte, tratando-se de imputação objetiva de danos (CC, art. 933). Os pais, nesse contexto sequer terão direito de regresso contra o descendente (CC, art. 934). Não se distingue, para efeitos da responsabilidade civil dos pais, se a incapacidade do menor é absoluta ou relativa $\left(\mathrm{CC}\right.$, art. $3^{\circ}$ e $\left.4^{\circ}\right)$. Naturalmente, é preciso que o menor tenha dado causa ao dano, pois, do contrário não haverá responsabilidade dos pais. Ao contrário da maior parte dos demais ordenamentos jurídicos, ${ }^{30}$ evitemos falar em ilicitude do fato do

\footnotetext{
${ }^{29}$ SALOMON Andrew. Longe da Árvore.: São Paulo: Companhia das letras, 2013, p. 440.

${ }^{30}$ Podemos ilustrar com o Código Civil da Argentina de 2015, que em seu artigo 1.754 prevê que:" Hecho de los hijos. Los padres son solidariamente responsables por los daños causados por los hijos que se encuentran bajo su responsabilidad parental y que habitan con ellos, sin perjuicio de la responsabilidad personal y concurrente que pueda caber a los hijos". A parte final do dispositivo deverá ser acrescida ao artigo 261 da lei civil, criando uma distinção vinculada pela idade entre maiores ou menores de 10 anos, no primeiro caso havendo discernimento para a prática de atos ilícitos, o que conduz a uma obrigação reflexa e concorrente dos pais com esses filhos.
} 
menor de 18 anos, que pressupõe a existência, no agente, de discernimento e livre determinação de vontade e atrairia uma responsabilidade concorrente dos pais com os descendentes.

O que fundamenta a responsabilidade civil, na hipótese, não é a culpa dos pais em não ter impedido o filho de praticar o dano. Quando o legislador delibera por substituir a presunção de culpa pela obrigação objetiva de indenizar, assume como nexo de imputação um verdadeiro dever de garantia afeto ao responsável por todos os danos causados pelo menor em face de terceiros, não se admitindo a exclusão da responsabilidade sob o pretexto de que tudo se fez para evitar o dano (sempre, porém, cabe lembrar, é possível alegar o rompimento do nexo causal).

É necessário, como visto, que o descendente seja incapaz. Porém, problema interessante se põe em relação aos danos causados por filhos maiores que não foram submetidos à modulação de capacidade. De acordo com a posição tradicional, os pais não respondem civilmente pelas condutas dos filhos maiores, ainda que estes não tenham patrimônio e morem com os pais. Com efeito, a doutrina clássica não hesitaria em afirmar: os pais não respondem. ${ }^{31}$ Essa ainda é a regra, sobremodo quando os danos exsurgem no exercício da atividade profissional dos filhos maiores ou do descumprimento de obrigações contratuais por eles assumidas.

Todavia, caberia questionar a razoabilidade de, em certos casos, deixar a vítima sem indenização. Sobretudo quando critérios objetivos apontam para a subsistência do binômio legal "autoridade e companhia" e simultaneamente indiquem que os pais ostentam confortável condição econômica, e tanto o autor do fato como vítima, pouco ou nada possuem. Se a curva demográfica aponta a inevitável tendência de filhos se

\footnotetext{
${ }^{31}$ A visão clássica, tradicional, acerca do tema está muito bem ilustrada nesta passagem de Alvino Lima, escrevendo sob a égide do Código Civil de 1916: "A menoridade é condição imprescindível da responsabilidade do genitor, pois, cessada a mesma com a maioridade, extingue-se o pátrio poder, e, consequentemente, o direito de guarda; os deveres de educação e vigilância cessam e o filho passa a agir livremente com a aquisição da capacidade absoluta" (LIMA, Alvino. A responsabilidade civil pelo fato de outrem. Rio de Janeiro: Forense, 1973. p. 35). Continua: "Ainda que o filho continue a viver na casa paterna, os seus atos não acarretam a responsabilidade do seu genitor, salvo a hipótese de responsabilidade pessoal proveniente de culpa pessoal, regulada pelo direito comum, como no caso, por exemplo, em que o filho tenha agido como preposto do próprio pai”. Lembremos, porém, que Alvino Lima - escrevendo, repita-se, sob a égide do Código Civil de 1916 - admitia, contra legem de certo modo (porquanto não tínhamos no Código Civil revogado norma semelhante ao art. 928 do Código atual), a responsabilidade direta do filho menor, desde que esse ostentasse capacidade de querer e de agir.
} 
enuclearem nos lares paternos mesmo cessada a juventude, ${ }^{32}$ naquilo que nos interessa, quanto mais grave a deficiência que afete o exercício do autogoverno, naturalmente a “autoridade fática" paterna sobressairá no exercício cotidiano dos atos da vida civil, atuando como uma espécie de gestor de negócios. Provavelmente pais e filhos residirão juntos e, como corolário lógico, qualquer fonte de renda da pessoa vulnerável não será suficiente para neutralizar os danos por ele causados.

Nesses casos específicos é imperioso encontrar uma solução hermenêutica adequada. Deixar vítimas de danos desamparadas seguramente não traduz as opções valorativas básicas registradas pela Constituição. A solução, segundo entendemos, está em responsabilizar solidariamente os pais e os autores do dano perante as vítimas, com a garantia, porém, do direito de regresso (que só não se aplica se o filho, causador do dano, for menor de 18 anos ou curatelado). ${ }^{33}$ Vítimas poderiam escolher entre litigar diretamente contra pais ou filhos (ou contra ambos caso queiram, por não se tratar de litisconsórcio passivo necessário), sem que se desrespeite a clássica exigência da imposição da solidariedade por lei, eis que a fonte atrativa da responsabilidade parental advém do art. 227 da CF. Os pais respondem, sendo-lhes assegurado, no entanto, a ação regressiva contra os filhos maiores, tal como ocorre nas demais hipóteses de responsabilidade por ato de outrem, respeitando-se o limite humanitário patrimonial do filho maior com deficiência, a teor do parágrafo único do art. 928, do Código Civil. A imputação da responsabilidade civil solidária aos pais pode ser a solução adequada, razoável e harmônica. ${ }^{34}$

As alternativas à responsabilidade solidária seriam duas: a) imposição de responsabilidade subsidiária aos guardiões apenas para os casos em que o responsável principal fosse insolvente; b) responsabilidade principal dos guardiões quando o autor

\footnotetext{
${ }^{32}$ Com a redação conferida pela EC 65/10 para o art. 227 da CF, pode-se mesmo indagar se é possível estender a responsabilidade objetiva dos pais pelos danos cometidos por filhos até os 29 anos de idade, idade limite para o conceito indeterminado "jovem" (art. 1. Lei 12.852/13 - Estatuto da Juventude), tendo em vista que a referida norma constitucional dilata o princípio da proteção integral da família, originariamente direcionado a crianças e adolescentes.

${ }^{33}$ Art. 934 do Código Civil: "Aquele que ressarcir o dano causado por outrem pode reaver o que houver pago daquele por quem pagou, salvo se o causador do dano for descendente seu, absoluta ou relativamente incapaz".

${ }^{34}$ Genevieve Viney, destacada especialista francesa do direito da responsabilidade civil, ainda em 1982 assinalava que: "se observa uma repugnância muito geral dos direitos modernos em relação à afirmação do caráter do ato defeituoso, mesmo aberrante, cometido por uma pessoa sem consciência de seus atos, mas, por outro lado, a maioria desses direitos se esforça para proporcionar, pelo menos, uma reparação parcial à vítima de tais atos com base em considerações de equidade". In: Les conditions de la responsabilité. 4. Ed. Paris : Librairie Générale de Droit et de Jurisprudence, 2013., p. 695.
} 
do dano estiver incapacitado judicialmente e subsidiária desse último, quando o cuidador seja insolvente. A mim me parece que dentre as três opções a solidariedade entre os responsáveis é a que melhor garante o princípio da mais ampla reparação em prol da vítima, sem que se elimine o posterior direito de regresso pela quantia correspondente em prol do responsável que realizou o pagamento. ${ }^{35}$

A responsabilidade dos pais oscilará entre objetiva ou subjetiva, conforme a intensidade da restrição psíquica ou intelectual do filho maior, autor do dano. Caso o agente seja privado de autodeterminação, pode ser caracterizado como sujeito formalmente capaz, porém materialmente incapaz, atraindo a responsabilidade objetiva de ambos os genitores por danos causados contra terceiros. Haveria uma lacuna, pois ao invés de uma incapacidade legal que derivaria em atribuição de responsabilidade aos curadores, surgiria uma incapacidade natural, sem que a lei elegesse responsáveis. Tal raciocínio autoriza os pais a simplesmente se eximirem da obrigação de indenizar, negligenciando o processo de curatela (cuja instauração é facultativa) ${ }^{36}$ e a consequente atribuição do múnus legal. Pode-se mesmo dizer que nesses casos extremos os pais estariam obrigados a promover a constituição da curatela - viabilizando proteção e cuidado ao filho ao se estabilizar os limites e extensão da curatela e a designação de um curador adequado - sendo que a omissão a esse dever acarretaria uma responsabilidade solidária pela indenização de danos por aquele causados, podendo a vítima agir contra o causador do dano ou os seus pais. ${ }^{37}$

Em sentido diverso, parece-nos inadequado cogitar de imputação objetiva de danos aos pais quando a deficiência do filho maior provoca tão somente uma redução em seu espaço deliberativo, mesmo que o autor do dano seja insolvente. As hipóteses de

\footnotetext{
${ }^{35}$ Lembramos que conforme os Princípios do direito europeu da responsabilidade civil "A pessoa sujeita a responsabilidade solidária tem direito de regresso frente a qualquer outra pessoa que seja responsável ante a vítima pelo mesmo dano...(3) a cota do direito de regresso será a que se considere justa a luz das respectivas responsabilidades pelo dano e qualquer outro aspecto relevante para estabelecer ou reduzir a responsabilidade. Se não se possa determinar a responsabilidade que corresponda a cada uma das pessoas, consideram-se responsáveis por igual...a obrigação de responder em via de regresso será parcial, isto é, a pessoa obrigada responde apenas pela cota de responsabilidade correspondente ao dano" (PETL, art. 9:102).

${ }^{36}$ Art. 747 CPC/15: A interdição pode ser promovida: I - pelo cônjuge ou companheiro; II - pelos parentes ou tutores; III - pelo representante da entidade em que se encontra abrigado o interditando; IV pelo Ministério Público.

${ }^{37}$ Nesse sentido caminha o art. 229 do Código Civil Espanhol "Estarán obligados a promover la constitución de la tutela, desde el momento en que conocieran el hecho que la motivare, los parientes llamados a ella y la persona bajo cuya guarda se encuentre el menor o incapacitado y, si no lo hicieren serán responsables solidarios de la indemnización de los daños y perjuicios causados" (conforme redação dada pela Lei 21/1987).
} 
responsabilidade objetiva demandam expressa enumeração legislativa. Ao contrário, a melhor forma de conciliar a proteção à esfera patrimonial e promoção de sua autonomia será autorizando a responsabilidade subjetiva dos pais, quando provada a omissão genérica quanto aos cuidados necessários ao tratamento do filho, ou a omissão específica no tocante à adoção de medidas de segurança e vigilância que poderiam evitar a causação do evento danoso, apesar da ciência quanto ao quadro clínico. ${ }^{38}$ Aplica-se a segunda parte do art. 942 do CC: “Os bens do responsável pela ofensa ou violação do direito de outrem ficam sujeitos à reparação do dano causado; e, se a ofensa tiver mais de um autor, todos responderão solidariamente pela reparação".

Aliás, em tais hipóteses, somos contrários a uma espécie de presunção de culpa dos pais por filhos adultos, o que colide frontalmente com o maior âmbito de autodeterminação e liberdade concedida pela Convenção de Nova York às pessoas com deficiência. ${ }^{39}$ Portanto, a cautela indica que se deve analisar a conduta do guardião em face das circunstâncias do caso concreto e dentro do que socialmente se considere razoável, pois se não fosse exigível dos pais uma forma distinta de atuar em cotejo daquela que se levou a cabo, serão eles exonerados de responsabilidade. Ilustrativamente, não será o guardião responsável por vigiar 24 horas por dia a pessoa enferma quando, atendidas as circunstâncias presentes (enfermidade concreta, nível de gravidade da mesma e grau de autonomia do sujeito), seria possível concluir que essa vigilância não era exigível. Entendemos que somente dessa forma compatibilizaremos os deveres de guarda e a possível responsabilidade do guardião em ponderação com a preservação da esfera de autogoverno do sujeito, afastando-se a errônea crença de que haveria uma automática relação de causa e efeito entre a falta de vigilância do guardião e o dano ocasionado pela pessoa maior com deficiência.

\footnotetext{
${ }^{38}$ STJ, Informativo 573 Período: 12 a 25 de novembro de 2015: "Os pais de portador de esquizofrenia paranoide que seja solteiro, maior de idade e more sozinho tem responsabilidade civil pelos danos causados durante os recorrentes surtos agressivos de seu filho, no caso em que eles, plenamente cientes dessa situação, tenham sido omissos na adoção de quaisquer medidas com o propósito de evitar a repetição desses fatos, deixando de tomar qualquer atitude para interditá-lo ou mantê-lo sob sua guarda e companhia" (REsp 1.101.324-RJ, Rel. Min. Antônio Carlos Ferreira, DJe 12/11/2015).

39 "Artigo 12: Reconhecimento igual perante a lei 1. Os Estados Partes reafirmam que as pessoas com deficiência têm o direito de ser reconhecidas em qualquer lugar como pessoas perante a lei. 2. Os Estados Partes reconhecerão que as pessoas com deficiência gozam de capacidade legal em igualdade de condições com as demais pessoas em todos os aspectos da vida".
} 
A propósito, em um ou outro caso, é interessante rememorar que, ao prever a responsabilidade por fato de outrem, o Código Civil (art. 932) faz surgir o dever de indenizar em hipóteses de escassa proximidade entre o responsável e o autor do dano, com fundamento em deveres de garantia perante potenciais vítimas. Nesse sentido, o sistema imputa responsabilidade por conduta alheia em diversas situações: os tutores respondem pelos atos dos tutelados; os empregadores respondem por atos dos empregados; os donos de hotéis, pelos atos dos hóspedes; os donos de escola, pelos atos dos alunos. Como afastar, nesse contexto, a responsabilidade dos pais pelos atos dos filhos maiores, máxime quando ainda vivem juntos e o autor do ilícito se encontrava em condição mitigada de autodeterminação ao tempo do evento danoso? A relação dos ascendentes com os descendentes, mesmo se já maiores, é incomparavelmente mais estreita do que a relação do empregador com o empregado, dos donos de hotéis com seus hóspedes e dos donos de escola com seus alunos.

Aliás, no que concerne à responsabilidade civil de estabelecimentos de educação (art. 932, IV , CC), no período em que o educando se encontra sob o poder de direção do estabelecimento, devemos compreender que a dita responsabilidade se aplica tão somente durante a menoridade (notadamente elidindo o dever de vigilância e a obrigação objetiva de indenizar por parte de instituições universitárias). Malgrado o silêncio do legislador, por simetria, tratando-se de pessoas maiores com deficiência, mesmo que capazes, haverá a responsabilidade objetiva dos centros de educação especial, pelo dever de vigilância que lhes é delegado desde a entrada até a saída do estabelecimento.

\subsection{A responsabilidade civil do guardião de fato por danos causados por idosos}

\subsubsection{A vulnerabilidade potencializada do idoso}

Na célebre obra de Balzac, a Comédia Humana, encontra-se o romance Père Goriot. É a história de um próspero empresário que doou todo o seu patrimônio a duas filhas, confiando receber delas carinho e apoio. Todavia, elas se casam com dois nobres e abandonam o pai. Com o passar do tempo, ele vai decaindo, chegando à extrema miséria. Rastignac, um jovem que vive na mesma pensão que Goriot, procura se relacionar com as filhas deste, transmitindo-lhes reiterados apelos do pai para que o 
visitem, até o momento da iminência de sua morte. Nem assim elas o visitam, sequer comparecem ao enterro. Enviam apenas as suas carruagens vazias para acompanhar o séquito. ${ }^{40}$

O direito privado despertou de uma longa letargia em relação ao tratamento jurídico que se deva conceder à pessoa idosa. Desafortunadamente, a civilística tradicional desumanizava o idoso pela lógica patrimonial da sua orgânica limitação para produzir patrimônio. Essa cultura de segregação perante àqueles que representassem um "estorvo" às relações econômicas, frequentemente impelia as famílias a neutralizar o idoso pela via da interdição e do isolamento. Mediante o alter ego de um curador normalmente um filho -, administrava-se o patrimônio daquele que alcançava a idade provecta. Simultaneamente, o idoso era excluído da convivência familiar por meio da internação em "asilos", verdadeiros depósitos humanos.

Nada obstante, como é cediço nos tempos atuais, se o idoso não for pessoa com deficiência psíquica, nem possua qualquer patologia que progressivamente retire o seu discernimento, jamais o fato isolado da idade avançada poderá impactar na formulação de normas ou de políticas públicas que suprimam a sua autonomia.

Em sede de direito à convivência, preferimos a clássica conceituação aristotélica de justiça como "dar às pessoas o que elas merecem". A lei não poderá ser neutra no que tange à qualidade de vida de crianças e adolescentes, cuja autonomia é um porvir, nem tampouco na qualidade de vida de idosos, cuja autonomia paulatinamente se esvaí. O ordenamento deverá se manifestar no tocante à constituição da subjetividade de nossos filhos e no cuidado com a preservação da estrutura psicofísica dos mais velhos e fragilizados, pois uma sociedade justa deve induzir os cidadãos a comportamentos virtuosos. Essa é a base de uma responsabilidade parental recíproca. Assim, o direito fundamental ao cuidado e ao amparo consiste não apenas em forte orientação ética, como em um compromisso constitucional com um dever de virtuosidade filial, promovendo o valor da importância da presença dos filhos adultos para a afirmação da dignidade dos pais no outono de suas vidas. A condição humana requer a pluralidade, seja em sua alvorada como em seus estertores. A entidade familiar se assume como

\footnotetext{
${ }^{40}$ Obviamente inspirada no Rei Lear, a narrativa demonstra a que ponto chega o amor paterno e o egoísmo humano (no caso, das filhas). Ao contrário de Shakespeare, Balzac optou por acentuar a maldade e ignorar a existência afetiva e redentora da filha Cordélia. O pai Goriot. São Paulo: Companhia das Letras, 2015.
} 
solidária não apenas quando pais edificam a autonomia de seus filhos, mas simetricamente quando os filhos preservam a autodeterminação dos pais que se tornam velhos. O cuidado é um dever imaterial imprescindível à estruturação psíquica de crianças, adolescentes e idosos.

O ponto de partida para o debate se encontra em dois dispositivos da Constituição Federal. A teor do art. 229: "Os pais têm o dever de assistir, criar e educar os filhos menores, e os filhos maiores têm o dever de ajudar e amparar os pais na velhice, carência ou enfermidade". Conforme o art. 230: "A família, a sociedade e o Estado têm o dever de amparar as pessoas idosas, assegurando sua participação na comunidade, defendendo sua dignidade e bem-estar e garantindo-lhes o direito à vida". Priorizar a dignidade do idoso, seja em sua dimensão negativa (respeito), como em sua vertente positiva (autonomia), é igualmente um dever da família, como se evidencia da letra dos mencionados artigos 229 e 230 da Constituição Federal. Com o objetivo de dar eficácia a essas normas, foi promulgada a Lei 10.741/2003, instituindo o Estatuto do Idoso, destinado a regular os direitos assegurados às pessoas com idade igual ou superior a 60 (sessenta) anos. Naquilo que fere diretamente ao tema, a referida lei cuida da dignidade do idoso de maneira qualitativamente diversa em função de sua condição de sujeito vulnerável, que resulta, tanto de sua natural assimetria em um contexto individual de declínio das potencialidades psicofísicas, como também de sua dificuldade de inserção em um ambiente social culturalmente marcado por práticas discriminatórias.

Com efeito, o idoso não é individualmente incapaz, porém compõe um grupo vulnerável. A incapacidade é um estado da pessoa que presume a sua vulnerabilidade, mas a recíproca não é válida. Os idosos, por suas peculiaridades, possuem uma gradação de vulnerabilidade acentuada, uma vulnerabilidade potencializada, ${ }^{41}$ situação fática que se manifesta em vários aspectos de sua vida. Idade avançada e deficiência são conceitos apartados, pois aquela não é necessariamente qualificada pela existência de impedimentos ao exercício das plenas potencialidades vitais. ${ }^{42}$ Não por outra razão, a

\footnotetext{
41 MARQUES, Cláudia Lima. Solidariedade na doença e na morte. Sobre a necessidade de ações afirmativas em contratos de plano de saúde e de planos funerários frente ao consumidor idoso. Revista trimestral de direito civil, Rio de Janeiro, v. 8, p.3-44, out./dez. 2001, p. 13.

${ }^{42}$ Heloisa Helena Barbosa explica que, "a proteção especial dos vulneráveis não se limita ao consumidor. A definição de vulnerabilidade compreende além da ideia de risco, outras como carência, inferioridade, constrangimento e sofrimento, não episódicos, mas "naturalizados", ínsitos a situação da pessoa. Por definição, todos os seres humanos são vulneráveis, mas não basta afirmar a vulnerabilidade que lhes é intrínseca para que recebam tutela adequada. Para tanto é indispensável verificar as peculiaridades das
} 
Lei 13.146/2015 (EPD) qualificou como especialmente vulnerável a pessoa idosa com deficiência, em virtude de impedimento de longo prazo de natureza física, mental, intelectual ou sensorial. ${ }^{43}$

A vulnerabilidade aumenta de forma diretamente proporcional ao crescimento da expectativa de vida e as mudanças demográficas, o que predispõe os mais velhos a doenças crônicas neurodegenerativas, com destaque ao Alzheimer, ${ }^{44}$ como principal causa de limitação de faculdades intelectivas e volitivas, sobremaneira a progressiva demência entre os idosos. Essa progressiva deterioração da capacidade não apenas converte os membros dessa faixa etária em alvo direto de agressões (inclusive abusos patrimoniais por parte da família), como também em potenciais criadores de riscos e danos para terceiros.

\subsubsection{A responsabilidade indireta do guardião}

A par da responsabilidade civil decorrente do ato ilícito praticado pelos filhos maiores e capazes que omitam o direito fundamental à convivência, privando os pais de companhia, visitação e apoio psicológico, há de se discutir de que forma surgirá para o guardião de fato a obrigação de reparar danos quando idosos violem a esfera existencial ou patrimonial de terceiros.

diferentes situações de cada indivíduo e/ou grupo. Desse modo é preciso distinguir a vulnerabilidade condição ontológica de qualquer ser vivo - da suscetibilidade ou vulnerabilidade secundária. Muitas pessoas têm a sua vulnerabilidade potencializada por problemas socioeconômicos ou de saúde e podem ser qualificados como vulnerados. Uma pessoa idosa é vulnerável, em razão do processo de envelhecimento, que pode atingir pessoas já vulneradas por doenças, pobreza ou deficiência física ou psíquica; estas estarão nitidamente em situação mais grave a exigir proteção diferenciada, diversa da conferida aos "apenas" idosos". In: A proteção dos vulneráveis na constituição de 1988. In: NEVES, Thiago Ferreira Cardoso (coord.). Direito e justiça social. São Paulo: Atlas, 2013, p. 107/10.

43 Art. 5ํํㄹ da Lei 13.146/15: "A pessoa com deficiência será protegida de toda forma de negligência, discriminação, exploração, violência, tortura, crueldade, opressão e tratamento desumano ou degradante". Parágrafo único: "Para os fins da proteção mencionada no caput deste artigo, são considerados especialmente vulneráveis a criança, o adolescente, a mulher e o idoso, com deficiência".

${ }^{44}$ A doença de Alzheimer é a causa de demência mais frequente em idosos, reforçando a associação entre demência e Alzheimer. Todavia, saímos de um período em que a DA era considerada rara, para uma situação em que casos de demências não relacionadas a ela são erroneamente diagnosticadas como tal", diz o neurologista Paulo Caramelli, professor titular da UFMG. Caramelli qualifica esse fenômeno de "alzheimerização". "Embora a doença de Alzheimer seja a principal causa de demência em idosos, uma coisa não é sinônimo da outra. De um lado, existem cerca de 100 enfermidades que causam demência; de outro, hoje se sabe que a DA também provoca alterações anteriores e mais leves". Extraído da Folha de São Paulo https://www1.folha.uol.com.br/equilibrioesaude/2018/04/alzheimerizacao-dedemenciaspreocupa-medicos-e-atrapalha-busca-por-tratamento. 
Já enfatizamos em outra passagem a própria responsabilidade do idoso perante a vítima do dano - esteja ele incapacitado ou não - quando ao tempo do evento lesivo possuía imputabilidade, ou seja, discernimento para compreender o alcance do fato ilícito cometido. Some-se a isso o próprio dado da experiência de que normalmente idosos possuem um patrimônio superior ao de seus guardiões de direito ou de fato, fato inverso ao que ocorre quando menores com solvência limitada causam danos, o que justifica que terceiros assumam a responsabilidade por um fato alheio.

Em acréscimo a isto, a responsabilidade solidária dos filhos maiores emerge do dever de garantia ínsito ao art. 229 da Constituição Federal e se torna ainda mais robusta nas específicas hipóteses em que a vulnerabilidade se intensifica, pelo fato da senectude do autor do ilícito se associar a um quadro de deficiência e carência de recursos para fazer frente à reparação integral.

Podemos ilustrar com um evento ocorrido em Barcelona, no qual um ancião de 77 anos de idade e enfermo mental provocou um incêndio na residência em que estava internado, ao não apagar corretamente o cigarro que fumava em sua habitação. $\mathrm{O}$ fogo não causou apenas a sua morte, como também a de seu companheiro de habitação. $O$ tribunal declarou que o "primeiro responsável" pelo ocorrido era o próprio idoso, que elidiu a proibição de fumar em razão da deterioração cognitiva progressiva da qual padecia. A questão que se abre é se ele poderia ser declarado responsável pelo dano causado. Deve responder pela violação de um dever de cuidado, independentemente de sua capacidade de discernimento para compreender a as consequências de seus atos? Apesar do magistrado ter reconhecido a deterioração psíquica do agente do dano, não a teve em conta ao momento de estimar a sua culpabilidade e consequente responsabilidade. ${ }^{45}$

Lateralmente à questão jurídica, há um dado da realidade que perpassa o cenário espanhol e também aqui se aplica: se, para além da responsabilização do próprio agente (no exemplo havia falecido), surge a obrigação de reparar danos para terceiros pelo fato alheio, vale dizer, a pessoa encarregada de seu cuidado, quem seria essa pessoa? Ocorre que não existe um tutor (não se trata de dano causado por menor) e provavelmente não

\footnotetext{
${ }^{45}$ Sentença de 1/2/2012 prolatada pela Audiência Provincial de Barcelona, extraída de ALBALADEJO, Maria Cristina Berenguer. Responsabilidad civil de la persona mayor con discapacidad. Madrid: Editorial Reus, 2017, p. 5-9.
} 
haverá um curador, pois é um dado da experiência que os familiares não submetem os idosos progressivamente acometidos de enfermidades à curatela. Não o fazem por uma gama de razões: a) culturalmente, por não haver por parte de filhos o mesmo interesse afetivo que pais teriam em despender tempo, energia e recursos no cuidado com pais idosos, inclusive por não ser muito clara a diferenciação dentre uma real causa e incapacitação ou apenas uma lenta degeneração que é fruto da idade avançada; b) historicamente, por se considerar que instituições de recolhimento idosos possam se prestar a esse papel; c) ideologicamente, por se acreditar que a curatela ofende a autonomia das pessoas idosas - sobremaneira após a edição da CDPD e leis nacionais que minudenciam a fundamentalidade da autodeterminação - e que o melhor será evitar o estigma da interdição, delegando-se àquelas pessoas a responsabilidade individual por suas próprias escolhas e comportamentos.

Esses fenômenos conjugados remetem a uma "crise da incapacitação", reduzindo-se paulatinamente o número de idosos com qualquer espécie de desordem mental cuja capacidade tenha sido modulada judicialmente. Consequentemente, apesar dessas pessoas se encontrarem parcialmente privadas de razão ou vontade para decidir sobre a sua pessoa ou patrimônio, encontram-se sob o cuidado de amigos, familiares ou em uma rede de apoio em residências de idosos. Para aquilo que especificamente nos interessa, devemos indagar: na falta de representante legal, essas pessoas, cujo cuidado e vigilância ostentam à margem do direito, podem ser responsabilizados pela "guarda de fato"? Como já tivemos a oportunidade de enfatizar, trata-se de um modelo jurídico de contornos pouco claros no direito brasileiros e cuja aplicação na seara da responsabilidade civil extracontratual merece enfoque para aclarar o vazio legislativo diante de danos injustos produzidos por pessoas plenamente capazes, todavia naturalmente incapacitadas ou com restrições na autodeterminação psíquica.

Como cediço, o guardião de fato não é inserido no rol dos objetivamente responsáveis pelo fato de terceiro do art. 932 do Código Civil. Solução distinta adotou o legislador alemão ao dispor que: “Quem, nos casos descritos nos parágrafos 823 a 826, não é responsável pelos danos causados por ele, de acordo com os parágrafos 827 e 828 , deve reparar o dano causado de qualquer maneira, desde que a compensação pelo dano não possa ser reclamada contra um terceiro obrigado por um dever de controle e se, de acordo com as circunstâncias, em particular, das relações entre os participantes, uma 
compensação de acordo com a equidade é exigida e ele não está privado dos meios que ele precisa para atender aos seus meios de subsistência adequados, bem como para o cumprimento de suas obrigações legais de alimentos" (parágrafo 829, BGB). O Código Civil alemão propõe que a reparação pelo guardião de fato seja subsidiária em relação à indenização exigida pelo "custodiante de direito". De qualquer forma, o mérito da norma consiste na ampliação do conceito de custódia, albergando não apenas os clássicos custodiantes legais (pais, tutores e curadores), porém qualquer pessoa que tenha o dever de controle sobre a causador material do dano.

De lega ferenda, o ideal seria que o art. 932, II, do Código Civil contemplasse os guardiões de fato dentre os responsáveis pelo fato de outrem. Apesar da literalidade do preceito, cremos que o fundamental é o nexo de hierarquia e subordinação que permita alguém dar ordens a outrem, mesmo que não se trate de uma curatela de direito, mas fática. Dentro do espírito da norma e da funcionalidade afim de ambos os modelos jurídicos, consideramos a viabilidade de uma intepretação extensiva da curatela, a fim de albergar uma instituição estruturalmente distinta, como a guarda de fato. Diante da irrecusável tendência de envelhecimento populacional associado a uma rejeição social ao processo de curatela - e na falta do prioritário apoio que promova a capacidade residual desses indivíduos -, é defensável a responsabilização de pessoas físicas ou jurídicas que tenham a seu cargo o dever de assistência, cuidado e vigilância sobre pessoas que tenham limitadas faculdades cognitivas e volitivas, independentemente de prévia modificação judicial de incapacidade.

Também defendemos a possibilidade de posterior exercício de direito regresso por parte do guardião de fato, por força do art. 934 do Código Civil, inclusive nos casos em que a reparação tenha sido efetuada pelo filho do ofensor idoso, eis que a norma somente coíbe o regresso em face de filhos menores e não de pais em situação de vulnerabilidade ou mesmo curatelados.

Contudo, a dúvida passa por saber se aplicaremos o regime de responsabilidade subjetiva ou objetiva. A nosso viso, a regra será a demonstração da prática de ilícito culposo pelo guardião, pois a falta de negligência conduzirá à exoneração de responsabilidade, mesmo nas hipóteses de insolvência da pessoa idosa. Cumpre analisar a conduta do guardião em si, a fim de se observar se dentro das circunstâncias concretas e do que socialmente se considera razoável não lhe era exigível uma forma de agir 
distinta da que levou a cabo. Só assim se alcança um equilíbrio entre a possível responsabilidade do guardião com a autonomia do sujeito sobre guarda. Entendimento contrário conduziria a uma objetivação da obrigação de indenizar mesmo não tendo praticado qualquer ato reprovável e tendo executado com certa diligência o dever de vigilância. A responsabilidade objetiva não pode ser aplicada analogicamente. Contudo, admitimos excepcionalmente uma imputação objetiva em face de familiares do idoso custodiado pelo dano causado a terceiros, quando o ofensor esteja sob a autoridade e companhia dos referidos familiares e em situação de absoluta ausência de autodeterminação, todavia sem ter sido submetido a processo de modulação de capacidade. A vítima não pode ser penalizada por não existir um curador que responderia objetivamente (art. 933, CC), o que seria um incentivo para que a família se contentasse com o exercício da guarda de fato mesmo em casos de incapacidade natural do idoso.

À medida que a guarda de fato de idosos seja aceita doutrinariamente e a consequente responsabilidade civil dos guardiões adentre a esfera dos tribunais, será importante dimensionar parâmetros de razoabilidade para o nível de diligência exigido das pessoas que têm a seu cargo um idoso que padeça de uma enfermidade psíquica, ponderando-se, entre outros extremos, a idade do idoso, a enfermidade, o conhecimento ou desconhecimento do guardião sobre a sua gravidade - e se esse desconhecimento era reprovável -, ou mesmo se uma atuação distinta do guardião para evitar o dano limitaria de forma irracional a esfera de liberdade do sujeito. ${ }^{46}$

\subsection{A responsabilidade civil nas hipóteses de dissociação entre a titularidade e o exercício efetivo da guarda}

Até o momento, vislumbramos situações em que surgirá a responsabilidade do guardador de fato ou mesmo do próprio causador do dano, se imputável. Nada obstante, o âmbito de responsabilidade poderá ser alargado nos casos em que este último seja

\footnotetext{
46 AlBALADEJO, Maria Cristina Berenguer. Responsabilidad civil de la persona mayor con discapacidad. Madrid: Editorial Reus, 2017, p.110/1. Assevera a autora que não se deve prestar a mesma atenção ou vigilância ao idoso demente no início de sua enfermidade, momento em que costuma ter maior propensão a causar danos devidos as alterações de comportamento que causam irritabilidade e rancor, do que nas posteriores fases da mesma, em que o enfermo pode estar mais tranquilo e por conseguinte, mais inofensivo. Op.cit., p. 110.
} 
relativamente incapaz e, mesmo contando com um curador, acaba por ingressar em um centro residencial, assistencial ou de saúde, culminando por ser atendido, cuidado e vigiado por pessoas diversas e desvinculadas do curador. Em tais hipóteses, sobre quem recairá a responsabilidade se a pessoa sob curatela causa um dano a terceiros?

A literalidade do art. 932, II, do Código Civil indica que o curador responderá somente quando a pessoa curatelada estiver sob a sua autoridade e companhia. Inexistente a convivência, o curador não assumiria as consequências do dano, até mesmo pelo fato de que a lei não exige que ambos convivam sob o mesmo teto. Supondo que seja conveniente a um zeloso curador internar o curatelado em um centro de atenção especializada, surgirá a responsabilidade da pessoa que venha a exercer efetivamente a vigilância e controle sobre aquele, havendo uma autêntica substituição da guarda legal, pois a execução material da função de cuidado da pessoa se realizará de forma permanente por um terceiro, que organizará e controlará a titulo permanente o seu modo de vida. Outrossim, a relação de dependência que se cria com o interno justifica a assunção da responsabilidade de clínicas, residências de terceira idade e centros geriátricos pelo dano ocasionado por ele em face de um terceiro. Apesar da pessoa jurídica pública ou privada responder como entidade - já que o dever de custódia se encomendou ao organismo e não a seus empregados - será viável o exercício do direito de regresso contra eventual pessoa natural cuja conduta negligente contribuiu para o dano. Não se olvide ainda que na prática estes centros contratam seguros de responsabilidade civil, transferindo eventuais danos para o patrimônio das empresas seguradoras.

Diversamente, poderíamos cogitar da responsabilidade do curador, quando tenha delegado as suas funções para alguém manifestamente incompetente para o exercício do dever de cuidado, o que facilitaria a prática do dano pela pessoa sob curatela contra outrem. Se aquele que se ocupou da vigilância imediata recebe retribuição pelos serviços contratados pelo curador, este responderá objetiva e solidariamente com o centro assistencial perante a vítima, tal e qual um empregador em razão da conduta negligente de seus empregados (932, III, CC).

Prosseguindo, tratamento distinto surgirá quando o curatelado cause danos quando alijado da companhia de seu curador por desídia exclusiva deste. Ou seja, a pessoa incapaz se encontrava em uma residência pois o curador havia lhe desamparado. 
Obviamente a responsabilidade do curador decorrerá do descumprimento das funções inerentes ao seu munus, sem prejuízo da responsabilidade da residência na qualidade de guardiã de fato. Aliás, em sentido estrito, só será possível recorrer ao instituto da guarda de fato quando a dissociação entre a titularidade e o exercício da guarda decorrer de um incumprimento de deveres pelo curador. Em contrapartida, nos casos em que a residência ou clínica se substitui contratualmente e com estabilidade ao curador, culmina por exercer um dever de vigilância a titulo permanente e respaldado por lei. $\mathrm{O}$ próprio art. 932, IV, do Código Civil estende a responsabilidade por fato de outrem aos “donos de hotéis, hospedarias, casas ou estabelecimentos onde se albergue por dinheiro, mesmo para fins de educação, pelos seus hóspedes, moradores e educandos", dispositivo cujo ratio incide perfeitamente sobre instituições que se ocupam do cuidado em caráter permanente, atraindo idêntico regime de responsabilidade objetiva pelos danos causados pelos custodiados contra terceiros (art. 933, CC).

Uma outra hipótese plausível concerne aos casos em que o curador coabita com o curatelado de forma estável, porém esporadicamente alguém - por cortesia ou amizade - encarrega-se de cuidar da pessoa incapacitada. É corriqueira a situação em que, pontualmente e de forma altruísta, vizinhos e familiares passeiam com a pessoa curatelada ou levam-na para compromissos médicos, somando-se a isto ocasiões em que algumas horas são dispendidas com profissionais remunerados como enfermeiros ou cuidadores profissionais. Em linha de princípio, a guarda ocasional não acarreta responsabilidade civil para tais pessoas, pois se cuidam de meros auxiliares do curador e não titulares da guarda de fato stricto sensu. ${ }^{47}$ Não houve uma delegação de faculdades ou uma substituição do curador por outrem, pois ele prossegue exercendo o controle e organizando de forma permanente o cotidiano do curatelado, apesar de suas ausências. Todavia, surgirá a obrigação de indenizar dos cuidadores esporádicos quando atuem com grave negligência ao tempo em que a pessoa privada de autodeterminação esteja sob o seu cuidado, tipicamente um inadimplemento de obrigação contratual de zelo na custódia que renderá à vítima a possibilidade de solidariamente responsabilizar o curador de direito e o cuidador de fato, com posterior direito de regresso daquele em

\footnotetext{
${ }^{47}$ MARTIN CASALS, "La responsabilidad por hecho ajeno en los "Principios de derecho europeo de la responsabilidad civil". O autor aclara que quando os princípios estabelecem a responsabilidade de "pessoas que tem outras sob o seu cuidado", não pretendem impor responsabilidade as pessoas que tem um menor ou deficiente psíquico sob a sua vigilância durante um breve lapso de tempo. In: Principios de derecho europeo de la responsabilidad civil. Madrid: Aranzadi, 2008.
} 
face deste, provada a exclusividade da omissão culposa do cuidador ocasional como causa do dano produzido a terceiros.

Por último, e de forma intermediária entre as hipóteses até agora suscitadas, cogitamos do evento danoso produzido pela pessoa custodiada quando passa grande parte do dia recebendo tratamento especializado em um centro assistencial, sem que, contudo, a instituição assuma o controle sobre a organização do modo de vida do paciente, porém interfira de uma forma mais intensa que uma mera custódia pontual. $\mathrm{O}$ "ingresso transitório" não consiste em uma espécie de guarda de fato. A guarda remanesce com a pessoa que a exercitava até o momento do ingresso, seja ela um dos pais, o curador ou etc. Poder-se-ia aqui aplicar a teoria da responsabilidade civil intermitente ou do trespasse de responsabilidade, pela qual o guardião inicialmente se responsabiliza pelos danos causados pela pessoa sob guarda a outrem, responsabilidade esta transferida aos centros, no período em que habitualmente se ocupem da vigilância e custódia diária, exatamente como se verifica diante dos danos cometidos por crianças e adolescentes no interior de estabelecimentos de ensino aos quais se delegam as funções de guarda e custódia. Por certo, provado que o centro assistencial em que o causador do dano ingressou é notoriamente inadequado, remanescerá a responsabilidade solidária do curador face ao desidioso exercício do dever de cuidado. ${ }^{48}$

\section{Conclusão}

Face ao conjunto de reflexões lançadas, alcançamos as seguintes conclusões:

I) A melhor forma de arbitrar a vulnerabilidade existencial da pessoa com deficiência será a de admitir a imputação direta das consequências econômicas do mau uso da liberdade, pela trasladação dos danos ao autor do ilícito, na qualidade de pessoa plenamente capaz, tal como refere o art. 927 do Código Civil. Todavia, o handicap do autor do dano justifica a atuação do princípio da equidade em termos de tutela

\footnotetext{
48 O Código Civil Argentino de 2015 expressamente articulou uma responsabilidade subjetiva dos estabelecimentos assistenciais: "Articulo 1756- Otras personas encargadas. Los tutores y los curadores son responsables como los padres por el daño causado por quienes están a su cargo. Sin embargo, se liberan si acreditan que les ha sido imposible evitar el daño; tal imposibilidad no resulta de la mera circunstancia de haber sucedido el hecho fuera de su presencia. El establecimiento que tiene a su cargo personas internadas responde por la negligencia en el cuidado de quienes, transitoria o permanentemente, han sido puestas bajo su vigilancia y control".
} 
diferenciada, não mais como próprio fundamento da responsabilidade (tal como se dá com o curatelado relativamente incapaz), porém, no âmbito exclusivo da mitigação do quantum reparatório, como exceção à regra da restitutio in integro do art. 944 do CC.

II) A adaptabilidade do modelo jurídico da guarda impele-nos a dilatar os seus contornos ao campo dos adultos vulneráveis, privados total ou parcialmente de autogoverno e cuja vigilância e assistência é produzida fora dos espaços jurídicos destinados à modulação de capacidade ou à tomada de decisão apoiada. Por conseguinte, nos planos estrutural e funcional a guarda de fato tanto poderá mimetizar a curatela como a TDA, recaindo sobre um heterogêneo universo de pessoas com ausência ou déficit de capacidade natural e que não são curateladas ou tampouco apoiadas.

III) É possível responsabilizar solidariamente pais e filhos adultos vulneráveis por danos perante as vítimas, com garantia do direito de regresso. Vítimas podem escolher entre litigar diretamente contra pais ou filhos, sem que se desrespeite a exigência da imposição da solidariedade por lei, eis que a fonte atrativa da responsabilidade parental advém do art. 227 da CF. Aos genitores é assegurada a ação regressiva contra os filhos maiores, respeitando-se o limite humanitário patrimonial do filho maior com deficiência, a teor do parágrafo único do art. 928, do CC. A imputação da responsabilidade civil solidária aos pais pode ser a solução adequada, razoável e harmônica.

IV) De lega ferenda, propõe-se que o art. 932, II, do Código Civil contemple os guardiões de fato dentre os responsáveis pelo fato de outrem. Apesar da literalidade do preceito, cremos que o fundamental é o nexo de hierarquia e subordinação que permita alguém dar ordens a outrem, mesmo que não se trate de uma curatela de direito, mas fática. Dentro do espírito da norma e da funcionalidade afim de ambos os modelos jurídicos, consideramos a viabilidade de uma intepretação extensiva da curatela, a fim de albergar uma instituição estruturalmente distinta, como a guarda de fato.

\section{Referências}

AGUIRRE, Carlos Martinez de. El tratamiento jurídico de la discapacidad psíquica: reflexiones para una reforma legal. Pamplona: Thomson Reuters - Aranzadi, 2014. 
ALBALADEJO, Maria Cristina Berenguer. Responsabilidad civil de la persona mayor con discapacidad. Madrid: Editorial Reus, 2017.

ALGUACIL, Maria José García. Protección Jurídica de las personas con discapacidad. Madrid, Reus: 2017.

BALZAC, Honoré de. O pai Goriot. Tradução: Rosa Freire D’Aguiar. São Paulo: Companhia das Letras, 2015.

BARBOSA, Heloisa Helena. A proteção dos vulneráveis na constituição de 1988. In: NEVES, Thiago Ferreira Cardoso (coord.). Direito e justiça social. São Paulo: Atlas, 2013.

BIANCA, Massimo. Diritto civile, 5, la responsabilità. Milano: Giuffrè, 2015.

HOYO, María Victoria Mayor del. Un nuevo modelo de protección de las personas con discapacidad. Pamplona: Thomson Reuters - Aranzadi, 2014.

LIMA, Alvino. A responsabilidade civil pelo fato de outrem. Rio de Janeiro: Forense, 1973.

MARQUES, Cláudia Lima. Solidariedade na doença e na morte. Sobre a necessidade de ações afirmativas em contratos de plano de saúde e de planos funerários frente ao consumidor idoso. Revista trimestral de direito civil, Rio de Janeiro, v. 8, p.3-44, out./dez. 2001.

MARTIN CASALS, Miquel. Principios de derecho europeo de la responsabilidad civil. Madrid: Aranzadi, 2008.

MORAES, Maria Celina Bodin de. Na medida da pessoa humana - Estudos de direito civil constitucional. Rio de Janeiro: Renovar, 2010.

MULHOLAND, Caitlin. A responsabilidade civil da pessoa com deficiência psíquica e/ou intelectual. In: MENEZES, Joyceane Bezerra (Org.). Direito das pessoas com deficiência psíquica ou intelectual nas relações privadas. Rio de Janeiro: Processo, 2016.

NEVES, Daniel Amorim Assumpção. Código de Processo Civil Comentado. Salvador: Juspodivm, 2017.

O'SHEA, Tom. A civic republican analysis of mental capacity law. In Legal studies The society of legal scholars. Volume 38 n. 1: Cambridge Press, March 2018.

PEREIRA, Rodrigo da Cunha Pereira. Dicionário de direito de família e sucessões. São Paulo: Saraiva, 2017.

SALOMON Andrew. Longe da Árvore. São Paulo: Companhia das Letras, 2013. 
VINEY, Genevieve. Les conditions de la responsabilité. 4. Ed. Paris: Librairie Générale de Droit et de Jurisprudence, 2013.

WATSON, Alan. Legal transplants: An approach to comparative law. 2. Ed. Athens, GA: University of Georgia Press, 1993.

Como citar: ROSENVALD, Nelson. A responsabilidade civil da pessoa adulta incapaz não incapacitada e a de seu guardião de fato por danos causados a terceiros. Revista IBERC, Minas Gerais, v. 1, n. 1, p. 01 - 43, nov.-fev./2019. 